Article

\title{
Chicken Astrovirus (CAstV) Molecular Studies Reveal Evidence of Multiple Past Recombination Events in Sequences Originated from Clinical Samples of White Chick Syndrome (WCS) in Western Canada
}

\author{
Victor Palomino-Tapia ${ }^{1}$ (), Darko Mitevski ${ }^{2}$, Tom Inglis ${ }^{3}$, Frank van der Meer ${ }^{1}$, Emily Martin ${ }^{4}$, \\ Marina Brash ${ }^{4}$, Chantale Provost ${ }^{5}$, Carl A. Gagnon ${ }^{5}$ and Mohamed Faizal Abdul-Careem ${ }^{1, *}$ \\ 1 Department of Ecosystem and Public Health, Faculty of Veterinary Medicine, University of Calgary, \\ Health Research Innovation Center 2C53, 3330 Hospital Drive NW, Calgary, AB T2N 4N1, Canada; \\ victor.palominotapia@ucalgary.ca (V.P.-T.); fjvander@ucalgary.ca (F.v.d.M.) \\ 2 Poultry Health Services, 1-4 East Lake Ave NE, Airdrie, AB T4A 2G8, Canada; \\ darko.mitevski@poultryhealth.ca \\ 3 The Institute of Applied Poultry Technologies, 201-151 East Lake Blvd, Airdrie, AB T4A 2G1, Canada; \\ tom.inglis@poultryhealth.ca \\ 4 Animal Health Laboratory, University of Guelph, Guelph, ON N1H 6R8, Canada; \\ eamartin@uoguelph.ca (E.M.); mbrash@uoguelph.ca (M.B.) \\ 5 Swine and poultry infectious diseases research center (CRIPA Fonds de Recherche du Quebec), \\ Molecular Diagnostic Laboratory, Faculty of veterinary medicine, University of Montreal, 3200 Sicotte, \\ Saint-Hyacinthe, QC J2S 2M2, Canada; chantale.provost@umontreal.ca (C.P.); \\ carl.a.gagnon@umontreal.ca (C.A.G.) \\ * Correspondence: faizal.abdulcareem@ucalgary.ca; Tel.: +01-403-220-4462; Fax: +01-403-210-9740
}

Received: 12 September 2020; Accepted: 25 September 2020; Published: 28 September 2020

\begin{abstract}
In this study, we aimed to molecularly characterize 14 whole genome sequences of chicken astrovirus (CAstV) isolated from samples obtained from white chick syndrome (WCS) outbreaks in Western Canada during the period of 2014-2019. Genome sequence comparisons showed all these sequences correspond to the novel Biv group from which no confirmed representatives were published in GenBank. Molecular recombination analyses using recombination detection software (i.e., RDP5 and SimPlot) and phylogenetic analyses suggest multiple past recombination events in open reading frame (ORF)1a, ORF1b, and ORF2. Our findings suggest that recombination events and the accumulation of point mutations may have contributed to the substantial genetic variation observed in $\mathrm{CAst} \mathrm{V}$ and evidenced by the current seven antigenic sub-clusters hitherto described. This is the first paper that describes recombination events in $\mathrm{CAstV}$ following analysis of complete CAstV sequences originated in Canada.
\end{abstract}

Keywords: chicken astrovirus; white chick syndrome; runting-stunting syndrome; molecular epidemiology; whole genome sequencing; recombination

\section{Introduction}

Chicken astrovirus (CAstV) [1], an enteric, non-enveloped, positive-sense RNA virus has recently emerged as an important poultry pathogen in broiler breeder flocks and their progeny across North America, Brazil, China, and several European countries including Poland, Finland, Norway, and United Kingdom [2-9]. Currently, the International Committee of Taxonomy of viruses (ICTV) in the latest 
2019 edition has classified CAstV, together with avian nephritis virus (ANV), as members of the Avastrovirus II species within the genus Avastrovirus, in the Astroviridae family [10,11]. It is worth to note that classification of astroviruses has changed several times since first descriptions were published in the late 1970s to early 1980s $[9,12,13]$. The genetic organization of CAstV is similar to other astroviruses as it is composed of a small, linear RNA of $\sim 7.5 \mathrm{~kb}$ in length, coding for three open reading frames (ORF): a non-structural protein (ORF1a), a viral RNA-dependent RNA polymerase (ORF1b, also named RdRp), and a capsid protein (ORF2) $[3,5,14,15]$. The capsid protein is highly variable, especially in its $3^{\prime}$ half of the ORF, which forms the external surface of the capsid forming the characteristically five or six-pointed star-like projections of astroviruses [16-18]. This area interacts with the cell receptor and is exposed to the host immune system $[3,5,16]$. The capsid protein has been divided into two major antigen groups with sub-divisions: Group A divided into three subgroups (i.e., Ai, Aii, and Aiii); and Group B divided into four subgroups (i.e., Bi, Bii, Biii, and Biv) [5].

Features of the capsid protein of $\mathrm{CAstV}$ are believed to drive the pathogenesis into three syndromes/diseases that are not mutually exclusive: (1) runting-stunting syndrome (RSS) characterized by malabsorption, enteritis, growth problems, and uneven flock performance [19]; (2) kidney disease and visceral gout characterized by high mortality in young broilers (up to 40\%) [20]; and white chick hatchery disease or white chick syndrome (WCS), a disease characterized by transient increase in mid to late embryo deaths, which causes a reduction in hatchability that can be as low as $4-5 \%$ and as high as $68 \%$ [21]. In WCS, some of hatched chicks are considered "white chicks", a condition characterized by pale plumage, weakness, slow weight gain, poor condition, and eventually death during the first days of life [3,6,21]. Lesions can be observed in kidney, liver, feathers, and intestine [3,5,6,21]. Although WCS has been known in Canada since the late 1980s-early 1990s, it has only recently been associated with CAstV in 2012 [4]. Improvements in surveillance and diagnostic assays have revealed an increased incidence of the problem, and its associated economic losses have rendered WCS a relevant emerging problem in poultry production in Canada $[4,22,23]$.

Transmission of $\mathrm{CAstV}$ can be horizontal, through the fecal-oral route; and probably vertical, although this has not been experimentally proven [3-5]. In the case of WCS, the virus can be detected in dead-in-shell embryos, meconium, and young chickens within the first week of life $[4,9,15]$. Progenitor broiler breeders of affected broiler flocks usually have a history ranging from no hatchability decrease or a decrease of $68 \%$ [3-5]. Many studies agree that progenitor flocks, naïve to CAstV, are challenged during production, experience a variable decrease in hatchability (with birds hatching as "white chicks"), and return to normal parameters after $\sim 4$ week period where they become seropositive by commercial CAstV Group B ELISA testing [3,5,24].

In contrast to our knowledge of the molecular and epidemiologic characteristics of $\mathrm{CAst} V$, our comprehension of CAstV pathogenesis is still scarce. Currently, the control of this disease is difficult due to its large geographical distribution, its horizontal, and likely vertical transmission, the environmental stability of the virus, and CAstV disinfection resistance. The lack of commercially-available vaccines may be in part due to the fact that $\mathrm{CAstV}$ is difficult to grow at immunogenic titers preventing cost-effective commercial vaccine production $[3,4,25]$. So far, the Canadian poultry industry is relying on strict biosecurity, increased down time between flocks, and effective disinfection of the premises. In some operations, the controversial practice of controlled-exposure by moving litter from CAstV ELISA-positive flocks into naïve pullet flocks is also used, despite the dangers of exposing naïve birds to other important pathogens such as Mycoplasma or Salmonella species.

Recently, several outbreaks of WCS were identified across Western Canada and Ontario. These outbreaks have caused sizable losses in Canadian poultry operations not only due to the detrimental effects of the disease, but also due to the sudden changes in allocation of day-old broiler chickens, which are of importance in the Canadian supply management system. We hypothesized that WCS cases detected since 2017 were associated with the presence of group B CAstV. Our objective was 
to characterize these CAstV isolates using Next Generation Sequencing (NGS) as a tool to study the genomic diversity of this virus in Western Canada.

\section{Materials and Methods}

\subsection{Sample Collection, Histopathology, and Processing}

Between December 2014-June 2019, a total of 17 samples from 12 clinical cases were diagnosed as WCS by Poultry Health Services (PHS, Airdrie, AB, Canada). Clinical samples, such as liver and intestines, were obtained from affected dead-in-shell embryos and young birds and tested by the Animal Health Laboratory (University of Guelph, Guelph, ON, Canada) for CAstV using quantitative polymerase chain reaction (qPCR) [23,26]. Affected tissues from some cases were also submitted to the same laboratory for histopathology examination for confirmation of diagnosis, and 17 samples from these clinical cases were held at $-80^{\circ} \mathrm{C}$ for further processing.

The liver and intestine samples were placed into sterile tubes prefilled with $1.0 \mathrm{~mm}$ zirconium beads (Benchmark Scientific Sayreville, NJ, USA), and $0.5 \mathrm{~mL} 1 \times$ phosphate buffered saline (PBS) (Gibco, Waltham, MA, USA) on ice, and homogenized (BeadBug, Benchmark Scientific, Sayreville, NJ, USA) during three series of 30 seconds each at 300 rounds per minute (RPM). Samples were incubated on ice for 3 minutes $(\mathrm{min})$ in between series. Following disruption, the samples were centrifugated at $7500 \times g$ for $30 \mathrm{~min}$ at $4{ }^{\circ} \mathrm{C}$ and the supernatant filtered using a $0.2 \mu \mathrm{M}$ syringe filter (Millipore Sigma, Burlington, MA, USA) and kept on ice for further processing.

\subsection{Virus Propagation}

Chicken embryo liver (CEL) cells were prepared using 14-day-old specific pathogen free (SPF) embryos obtained from the Canadian Food Inspection Agency (CFIA) (Ottawa, Canada). It has been shown previously that CEL can be infected with a variety of poultry viruses [27-32], including CAstV $[1,33]$. The use of embryos was approved by the institutional animal care committee, Health Science Animal Care Committee (HSACC). Livers were obtained from embryos following aseptic technique, minced, trypsinized (Gibco, Carlsbad, California, USA), and cultured in T25 flasks as previously described [29]. CELs were propagated in Dulbecco's Modified Eagle's Medium (DMEM) with 10\% fetal bovine serum (FBS), and $100 \mathrm{U} / \mathrm{mL}$ penicillin, and $100 \mu \mathrm{g} / \mathrm{mL}$ streptomycin (Gibco, Carlsbad, California, USA). After viral infection, with processed samples (supernatants), similar media was used (except that $2 \%$ calf serum (CS) was used instead of $10 \%$ FBS). Cells were incubated at $37^{\circ} \mathrm{C}$ with $5 \% \mathrm{CO}_{2}$. Three passages in CEL were performed before ribonucleic acid (RNA)-extraction, complimentary deoxy ribonucleic acid (cDNA) conversion, and PCR for detection of CAstV by qPCR $[23,26]$.

\subsection{RNA Extraction, Reverse Transcription, $q P C R$, and Sequencing}

Total RNA was extracted from infected CEL cultures supernatants, obtained after centrifugation at $7500 \times g$ for $30 \mathrm{~min}$ at $4{ }^{\circ} \mathrm{C}$ and the supernatant filtered using a $0.2 \mu \mathrm{M}$ syringe filter (Millipore Sigma, Burlington, MA, USA), using TRIzol Reagent (Invitrogen, Carlsbad, CA), according to manufacturer's instructions with modifications. In short, a total of $\sim 1.5 \mathrm{~mL}$ of filtrated supernatant was pooled. The extracted RNA was used as template for reverse-transcription (RT) PCR using high-capacity cDNA reverse transcription kit (Applied Biosystems, Foster City, CA, USA) for cDNA synthesis using random primers following manufacturer's instructions. The RT-PCR reaction mix consisted of $4 \mu \mathrm{L} 10 \times \mathrm{RT}$ Random Primers, $2 \mu \mathrm{L}$ 10× RT Buffer, 4 mM dNTP Mix, $2 \mu \mathrm{L}$ MultiScribe ${ }^{\mathrm{TM}} \mathrm{RT}, 8.4 \mu \mathrm{L}$ nuclease free $\mathrm{H}_{2} \mathrm{O}$, and a $20 \mu \mathrm{L}$ RNA template for a total of $40 \mu \mathrm{L}$ reaction mix. RT-PCR thermocycler conditions consisted of three steps: Step 1-Incubation, $25^{\circ} \mathrm{C}$ for $10 \mathrm{~min}$; Step 2-Reverse Transcriptase, $37^{\circ} \mathrm{C}$ for $120 \mathrm{~min}$; and Step 3, Reverse transcriptase inactivation, $85^{\circ} \mathrm{C}$ for $5 \mathrm{~min}$. The qPCR assay was conducted using PerfeCTa SYBR Green SuperMix (Quantabio, Beverly, MA, USA) using cDNA as a template. The qPCR reaction mix was used using published primers by Smyth et al. 2010 [23] and consisted on $12.5 \mu \mathrm{L}$ PerfeCTa SYBR $2 \times$ Buffer, $0.5 \mu \mathrm{M}$ CAstV Forward Primer (5'-GCYGCTGCTGAAGAWATACAG-3'), 0.5 
$\mu \mathrm{M}$ Reverse Primer (5'-CATCCCTCTACCAGATTTTCTGAAA-3'); $5 \mu \mathrm{L}$ nuclease free $\mathrm{H}_{2} \mathrm{O}$; and $5 \mu \mathrm{L}$ cDNA template for a total of $25 \mu \mathrm{L}$ reaction. The qPCR thermocycler conditions consisted of an initial denaturation cycle of $95^{\circ} \mathrm{C}$ for $3 \mathrm{~min}$, and 39 cycles of $95^{\circ} \mathrm{C}$ for 15 seconds, $60{ }^{\circ} \mathrm{C}$ for 45 seconds. At the end of the amplification, a melting curve analysis was performed to verify the proper melting temperature of the amplicons. Conditions of the melt curve protocol consisted of 5 seconds at $65^{\circ} \mathrm{C}$ and then 5 seconds each at $0.5^{\circ} \mathrm{C}$ increments between $65^{\circ} \mathrm{C}$ and $95^{\circ} \mathrm{C}$. Post-run qPCR amplification and melt-curve data were analyzed using the Bio-Rad CFX Maestro 1.1 software (v4.1.2433.1219) for positive identification of CAstV in the samples. Quantification (Nanodrop 1000, ThermoScientific, Wilmington DE, USA) of the cDNA was performed before submission for NGS using a Nextera XT library and the v3 600 cartridge (MiSeq, Illumina, San Diego, CA, USA) at the Faculty of Veterinary Medicine of University of Montreal, Montreal, QC, Canada. Prior to second strand synthesis, $1 \mu \mathrm{L}$ RNAse H (New England Biolabs, MA, USA) was added to $20 \mu \mathrm{L} \mathrm{cDNA}$ to hydrolyze the RNA strand of the cDNA:RNA hybrid double strand, followed by a 20 min incubation at $37^{\circ} \mathrm{C}$. Then, $1 \mu \mathrm{L} 60 \mu \mathrm{M}$ Random Primers and $22 \mu \mathrm{L}$ of nuclease free $\mathrm{H}_{2} \mathrm{O}$ were incubated for $5 \mathrm{~min}$ at $65^{\circ} \mathrm{C}$. Second strand synthesis was done using $5 \mu \mathrm{L} 10 \times$ Buffer 2 and $1 \mu \mathrm{L}$ Klenow Fragment $\left(3^{\prime} \rightarrow 5^{\prime}\right.$ exo-) at $25^{\circ} \mathrm{C}$ for $5 \mathrm{~min}, 37^{\circ} \mathrm{C}$ for $50 \mathrm{~min}$, and $75^{\circ} \mathrm{C}$ for $15 \mathrm{~min}$. Synthesized double stranded DNA (dsDNA) was cleaned with 1.8X Axygen AxyPrep Mag PCR Clean-up beads (Corning, NY, USA) following the manufacturer's protocol. Quantification of dsDNA was performed using HS DNA Assay Kit in a Qubit 3.0 Fluorometer (Invitrogen, CA, USA). Libraries were generated using Nextera XT DNA Library Preparation Kit (Illumina, CA, USA). Briefly, $0.3 \mathrm{ng} / \mathrm{mL}$ of dsDNA was used to start the libraries. Fragmentation and tagmentation was performed as suggested by the company's protocol. Amplification and indexing were also performed as described in the company's protocol. Libraries were then purified using AxyPrep MagTM PCR Clean-up Kits (Corning, NY, USA) as described in the Nextera XT protocol. Library's quality was assessed using Agilent High Sensitivity DNA Kit in a Bioanalyzer (Agilent, CA, USA). Libraries were normalized using LNB1 beads (Nextera XT protocol). Libraries were sequenced in a v3 600 cartridge using a MiSeq instrument and PhiX at around $1 \%$ as control for the sequencing runs (Illumina, CA, USA).

\subsection{Data Analysis and Phylogenetic Analysis}

NGS short reads were mapped to the CAstV isolate CkP5 (GenBank accession\# KX397576), under App Map function of CLC Genomics Workbench v 12.0.2 (Qiagen, Valencia, CA, USA) using default settings. Whole genome sequences were aligned using MAFFT v7.450 [34,35], and phylogenetic trees were generated using RAxML v8.2.11. This was possible by applying the nucleotide model GTR+gamma with Rapid bootstrapping and searching for best-scoring ML tree with 1000 bootstrap replicates, with parsimony random seed 400,000 as in previous studies concerning other RNA-viruses [36-38]. It is worth to mention that selection of this model over others was done based on its high frequency in similar studies, albeit it is expected that different models will lead to very similar results according to Abadi, et al. 2019 [38]. ORF1a, ORF1b, and ORF2 nucleotide and amino acid (aa) alignments were performed using Clustal Omega v1.2.2. and phylogenetic trees were generated using RAxML applying the protein model BLOSUM62+gamma with Rapid bootstrapping and search for best-scoring ML tree with 1000 bootstrap replicates, with parsimony random seed 400,000. All the sequences were deposited in GenBank (Table 1). For phylogenetic analysis on ORF2, 38 aa sequences from $\mathrm{CAstV}$ reference strains and field sequences from different locations around the world were retrieved from GenBank and included in the study (Table 2) [4,5]. The CAstV classification based on ORF2 aa sequence was based on two criteria: (1) Bootstrap values of the RAxML phylogenetic trees with 1000 replicates, and (2) percentage of identity matrix resulting from the RAxML phylogenetic tree as in a previous publication based on a different virus, avian reovirus [37]. 
Table 1. List and classification of $14 \mathrm{CAstV}$ isolates deposited in GenBank and background information.

\begin{tabular}{|c|c|c|c|c|c|c|c|c|}
\hline$\#$ & $\begin{array}{l}\text { CAstV } \\
\text { ID e }\end{array}$ & $\begin{array}{l}\text { Capsid } \\
\text { Genotyping }\end{array}$ & Origin & Province & $\begin{array}{l}\text { Breeder } \\
\text { Age }\end{array}$ & Age & Clinical Case & $\begin{array}{l}\text { GenBank } \\
\text { Accession }\end{array}$ \\
\hline 1 & $14-1235 \mathrm{a}$ & $\mathrm{Biv}$ & Liver & $\mathrm{AB}$ & $30 \mathrm{~W}$ & $1 \mathrm{DOA} b$ & \multirow{2}{*}{$\begin{array}{c}\text { Flock A. Drop in production, very poor } \\
\text { hatchability and poor viability of } \\
\text { hatched chicks. }\end{array}$} & MT789774 \\
\hline 2 & $14-1235 \mathrm{~b}$ & Biv & Intestine & $A B$ & $30 \mathrm{~W}$ & $1 \mathrm{ROA}$ & & MT789775 \\
\hline 3 & $14-1235 \mathrm{c}$ & Biv & Intestine & $\mathrm{AB}$ & $28 \mathrm{~W}$ & $1 \mathrm{DOA}$ & \multirow{2}{*}{$\begin{array}{c}\text { Flock B. Drop in production, very poor } \\
\text { hatchability and poor viability of } \\
\text { hatched chicks. }\end{array}$} & MT789776 \\
\hline 4 & $14-1235 \mathrm{~d}$ & Biv & Liver & $\mathrm{AB}$ & $28 \mathrm{~W}$ & $1 \mathrm{DOA}$ & & MT789777 \\
\hline 5 & $15-1262 \mathrm{a}$ & Biv & Liver & $\mathrm{AB}$ & $32 \mathrm{~W}$ & $1 \mathrm{DOA}$ & \multirow{2}{*}{$\begin{array}{c}\text { Flock A. Poor hatchability. Slow hatching eggs. } \\
\text { Red hocks on many chicks, yellow livers. No } \\
\text { white chicks. }\end{array}$} & MT789778 \\
\hline 6 & $15-1262 b$ & Biv & Liver & $\mathrm{AB}$ & 3 & $1 \mathrm{D}$ & & MT789779 \\
\hline 7 & $15-1262$ c & Biv & Liver & $\mathrm{AB}$ & $33 \mathrm{~W}$ & $1 \mathrm{DOA}$ & \multirow{2}{*}{$\begin{array}{c}\text { Flock B. Poor hatchability. Slow hatching eggs. } \\
\text { Increased culls with green livers and } \\
\text { white chicks. }\end{array}$} & MT789780 \\
\hline 8 & $15-1262 \mathrm{~d}$ & Biv & Liver & $\mathrm{AB}$ & $33 \mathrm{~W}$ & $1 \mathrm{DOA}$ & & MT789781 \\
\hline 9 & $17-0773$ a & Biv & Liver & $\mathrm{AB}$ & $30 \mathrm{~W}$ & $\sim 20 \mathrm{DOE} \mathrm{c}$ & \multirow{2}{*}{$\begin{array}{c}\text { Flock A. Poor hatchability. Increased culls } \\
\text { were weak with green livers and } \\
\text { white feathering. }\end{array}$} & MT789782 \\
\hline 10 & $17-0773 \mathrm{~b}$ & Biv & Liver & $\mathrm{AB}$ & $30 \mathrm{~W}$ & $1 \mathrm{DOA}$ & & MT789783 \\
\hline 11 & $17-0823$ & Biv & Liver & $\mathrm{AB}$ & $\mathrm{NDa}$ & $6 \mathrm{DOA}$ & $\begin{array}{l}\text { High first week mortality at } 0.25 \% \text { per day- } \\
\text { RSS d with swollen/pale kidneys and } \\
\text { mottled livers. }\end{array}$ & MT789784 \\
\hline 12 & 18-0942 & Biv & Liver & SK & $40 \mathrm{~W}$ & $1 \mathrm{DOA}$ & $\begin{array}{l}\text { Fertility } 92 \% \text {; hatchability } 79 \% \text {. High number } \\
\text { of culls, } 70 \% \text { of them small and white with } \\
\text { bronze/tan livers. }\end{array}$ & MT789785 \\
\hline 13 & 19-0935 & Biv & Liver & SK & $28 \mathrm{~W}$ & $1 \mathrm{DOA}$ & $\begin{array}{l}\text { Fertility } 81 \% \text {; hatchability } 68.9 \% \text {; Culls } 2-90 \% \\
\text { of culls were white. }\end{array}$ & MT789786 \\
\hline 14 & 19-0981 & Biv & Liver & SK & $38 \mathrm{~W}$ & $1 \mathrm{DOA}$ & $\begin{array}{l}\text { Fertility } 92.2 \% \text {; hatchability } 84.3 \% \text {; Culls } \\
\quad 1.42 \%-25-30 \% \text { culls are white. }\end{array}$ & MT789787 \\
\hline
\end{tabular}

${ }^{\mathrm{a}}$ ND—No Data. ${ }^{\mathrm{b}}$ DOA—Days of Age. ${ }^{\mathrm{c}}$ DOE-Days of Embryonation. ${ }^{\mathrm{d}}$ RSS-Runting-Stunting Syndrome. ${ }^{\mathrm{e}}$ Number on name of CAstV ID correspond to clinical case. Some clinical cases were created by Hatchery. Thus, the letters following the number are used to differentiate some isolates in regards of Farm, organ, or age of bird/embryo.

\subsection{Recombination Analysis}

To identify the presence of recombinant sequences, a multiple sequence alignment was performed including all 24 complete $C A s t V$ sequences using MAFFT v7.450 [34,35] (Table 2). The sequence analysis was analyzed in RDP5 software v. 5.5 [39-41], which is a software that applies several recombination and analysis methods on a set of data. In this research, data was analyzed using the following recombination methods: (1) RDP method [40]; (2) GENECONV [42]; (3) Bootscan/Recscan method [39]; (4) MaxChi method [43]; (5) Chimaera method [44]; (6) SiScan Method [45]; and (7) 3-seq [46]. Recombination events were detected by at least 6 of these 7 methods. Putative recombination sequences were further investigated by using Bootscan analysis within the Simplot program version 3.5.1 [47], using the following parameters: window size $=400 \mathrm{bp}$; step size $=40 \mathrm{bp}$; GapStrip = On; Repetitions $=100$; Kimura 2-parameter substitution model; $\mathrm{T} / \mathrm{t}=2$; and using the neighbor-joining method [47-49].

Table 2. List of all CAstV sequences in the study with GenBank Accession Numbers.

\begin{tabular}{|c|c|c|c|c|c|c|c|}
\hline \multirow{2}{*}{ Sequence } & \multirow{2}{*}{ Genotype } & \multicolumn{4}{|c|}{ Phylogenetic Tree } & \multirow{2}{*}{$\begin{array}{c}\text { GenBank } \\
\text { Number }\end{array}$} & \multirow{2}{*}{$\begin{array}{c}\text { Paper } \\
\text { Published }\end{array}$} \\
\hline & & Whole Genome & ORF1a & ORF1b & ORF2 & & \\
\hline $14-1235 a-A B$ & Biv & $x$ & $x$ & $x$ & $x$ & MT789774 & \multirow{9}{*}{ This Study } \\
\hline $14-1235 b-A B$ & Biv & $x$ & $x$ & $x$ & $x$ & MT789775 & \\
\hline $14-1235 c-A B$ & Biv & $x$ & $x$ & $x$ & $x$ & MT789776 & \\
\hline $14-1235 \mathrm{~d}-\mathrm{AB}$ & Biv & $x$ & $x$ & $x$ & $x$ & MT789777 & \\
\hline $15-1262 a-A B$ & Biv & $x$ & $x$ & $x$ & $x$ & MT789778 & \\
\hline $15-1262 b-A B$ & Biv & $x$ & $x$ & $x$ & $x$ & MT789779 & \\
\hline $15-1262 c-A B$ & Biv & $x$ & $x$ & $x$ & $x$ & MT789780 & \\
\hline $15-1262 d-A B$ & Biv & $x$ & $x$ & $x$ & $X$ & MT789781 & \\
\hline 17-0773a-AB & Biv & $x$ & $x$ & $x$ & $x$ & MT789782 & \\
\hline
\end{tabular}


Table 2. Cont.

\begin{tabular}{|c|c|c|c|c|c|c|c|}
\hline \multirow{2}{*}{ Sequence } & \multirow{2}{*}{ Genotype } & \multicolumn{4}{|c|}{ Phylogenetic Tree } & \multirow{2}{*}{$\begin{array}{c}\text { GenBank } \\
\text { Number }\end{array}$} & \multirow{2}{*}{$\begin{array}{c}\text { Paper } \\
\text { Published }\end{array}$} \\
\hline & & Whole Genome & ORF1a & ORF1b & ORF2 & & \\
\hline $17-0773 b-A B$ & Biv & $X$ & $X$ & $X$ & $X$ & MT789783 & \\
\hline $17-0823-\mathrm{AB}$ & Biv & $X$ & $X$ & $X$ & $X$ & MT789784 & \\
\hline 18-0942-SK & Biv & $x$ & $x$ & $x$ & $x$ & MT789785 & \\
\hline 19-0935-SK & Biv & $X$ & $X$ & $X$ & $X$ & MT789786 & \\
\hline 19-0981-SK & Biv & $x$ & $x$ & $x$ & $X$ & MT789787 & \\
\hline HBLP717-1/CN/2018* & $\mathrm{Bi}$ & $X$ & $x$ & $X$ & $X$ & MN725025 & \multirow[b]{2}{*}{ [2] } \\
\hline GDYHTJ718-6/CN/2018 * & $\mathrm{Bi}$ & $X$ & $x$ & $X$ & $X$ & MN725026 & \\
\hline GA2011/US/2011 ** & Bii & $x$ & $X$ & $x$ & $x$ & JF414802 & \multirow{3}{*}{ [15] } \\
\hline CkP5/US/2016 ** & Biv & $x$ & $x$ & $x$ & $x$ & KX397576 & \\
\hline CC_CkAstV/US/2014 ${ }^{* *}$ & Biv & $x$ & $x$ & $x$ & $x$ & KX397575 & \\
\hline ANAND/IN/2016 *** & Biii & $x$ & $x$ & $x$ & $x$ & KY038163 & [50] \\
\hline G059/PL/2014 **** & Aiii & $x$ & $x$ & $x$ & $x$ & KT886453 & [51] \\
\hline 4175/US/2011 ** & Bii & $x$ & $\mathrm{X}$ & $X$ & $x$ & JF832365 & $\begin{array}{c}\text { Unpublished, } \\
2011 \\
\end{array}$ \\
\hline CZ1701/CN/2017* & $\mathrm{Bi}$ & $x$ & $x$ & $x$ & $x$ & MN807051 & \multirow{2}{*}{$\begin{array}{c}\text { Unpublished } \\
2019\end{array}$} \\
\hline NJ1701/CN/2017 * & $\mathrm{Bi}$ & $X$ & $x$ & $X$ & $X$ & MK746105 & \\
\hline 612 & $\mathrm{Ai}$ & & & & $x$ & JN582317 & \multirow{24}{*}{ [5] } \\
\hline P22-18.8.00 & $\mathrm{Ai}$ & & & & $x$ & JN582318 & \\
\hline VF08-56 & $\mathrm{Ai}$ & & & & $x$ & JN582319 & \\
\hline VF08-60 & $\mathrm{Ai}$ & & & & $x$ & JN582320 & \\
\hline VF08-54 & Aii & & & & $X$ & JN582323 & \\
\hline VF08-18/7 & Aii & & & & $X$ & JN582324 & \\
\hline VF08-36 & Aii & & & & $X$ & JN582325 & \\
\hline VF08-48 & Aii & & & & $X$ & JN582326 & \\
\hline VF08-46 & Aiii & & & & $X$ & JN582321 & \\
\hline VF08-65 & Aiii & & & & $X$ & JN582322 & \\
\hline 1010 & $\mathrm{Bi}$ & & & & $x$ & JN582306 & \\
\hline 11522 & $\mathrm{Bi}$ & & & & $x$ & JN582305 & \\
\hline 11672 & $\mathrm{Bi}$ & & & & $x$ & JN582327 & \\
\hline FP3 & $\mathrm{Bi}$ & & & & $X$ & JN582328 & \\
\hline VF06-1/1 & $\mathrm{Bi}$ & & & & $x$ & JN582307 & \\
\hline VF06-1/2 & $\mathrm{Bi}$ & & & & $x$ & JN582308 & \\
\hline VF06-1/4 & $\mathrm{Bi}$ & & & & $X$ & JN582309 & \\
\hline VF06-7/5 & $\mathrm{Bi}$ & & & & $X$ & JN582310 & \\
\hline VF06-7/8 & $\mathrm{Bi}$ & & & & $X$ & JN582311 & \\
\hline 05V150/152/154 & Bii & & & & $x$ & JN582312 & \\
\hline VF06-7/3 & Bii & & & & $x$ & JN582313 & \\
\hline VF07-4/2 & Bii & & & & $x$ & JN582314 & \\
\hline VF08-29 & Bii & & & & $X$ & JN582315 & \\
\hline VF08-3 & Bii & & & & $x$ & JN582316 & \\
\hline PDRC/200/EastZone & Biii & & & & $x$ & JX945853 & \multirow{4}{*}{$\begin{array}{l}\text { Unpublished } \\
2013\end{array}$} \\
\hline PDRC/526/NorthZone & Biii & & & & $x$ & JX945857 & \\
\hline PDRC/573/WestZone & Biii & & & & $x$ & JX945861 & \\
\hline PDRC/447/SouthZone & Biii & & & & $x$ & KC618323 & \\
\hline
\end{tabular}

${ }^{*} \mathrm{CN}$ refers to China as origin of the sequence; ${ }^{* *}$ US refers to United States as the origin of the sequence; ${ }^{* * *}$ IN refers to India as the origin of the sequence; ${ }^{* * * *}$ PL refers to Poland as the origin of the sequence.

\section{Results}

\subsection{Clinical Background, Gross Lesions, and Histopathology}

The hatching of WCS-affected broilers on the diagnosed clinical cases was characterized by low uniformity, increased culls with green livers and white feathering (Figures 1 and 2d). Records of 
hatchability losses, when available, ranged between 5 and $16 \%$, and occurred mainly in the mid and late incubation periods (Table 1). Dead-in-shell embryos were characterized by enlarged firm livers ranging from bronze to bright green with occasional necrotic areas with large, underutilized, and unabsorbed yolk-sac contents with visible green discoloration (Figure 2a,b). Some embryos were found covered in what would appear to be urates. Cull chicks were characterized by small size, depression, weak upon stimulation, and frequently white plumage (Figure 1a). Upon necropsy, green livers, and dark-green unabsorbed yolks were observed in these birds (Figure 2b). In some instances (17-0823), high mortality was observed during the first week of life in flocks apparently mildly affected with WCS during hatching. In this case, 6 day of age (DOA) were submitted with a history of high first week mortality of about $0.25 \%$ per day, RSS, and swollen/pale kidneys and mottled livers together with yolk sac infection. The age of submission of the cases included in this study was between 18 DOE, and the latest at $6 \mathrm{DOA}$, with a median of 1 DOA. These cases came from broiler breeder flocks between 28 and 40 weeks of age with most of the cases occurring from progenitors at the beginning of the production cycle, between 28 and 33 weeks. Clinical necropsies and sample collections from submitted cases were performed by veterinarians and trained PHS personnel at the post-mortem facility at the Veterinary Professional Center (Airdrie, AB, Canada), following guidelines approved by the Alberta Veterinary Medical Association, the CFIA, and the Public Health Agency of Canada (PHAC).

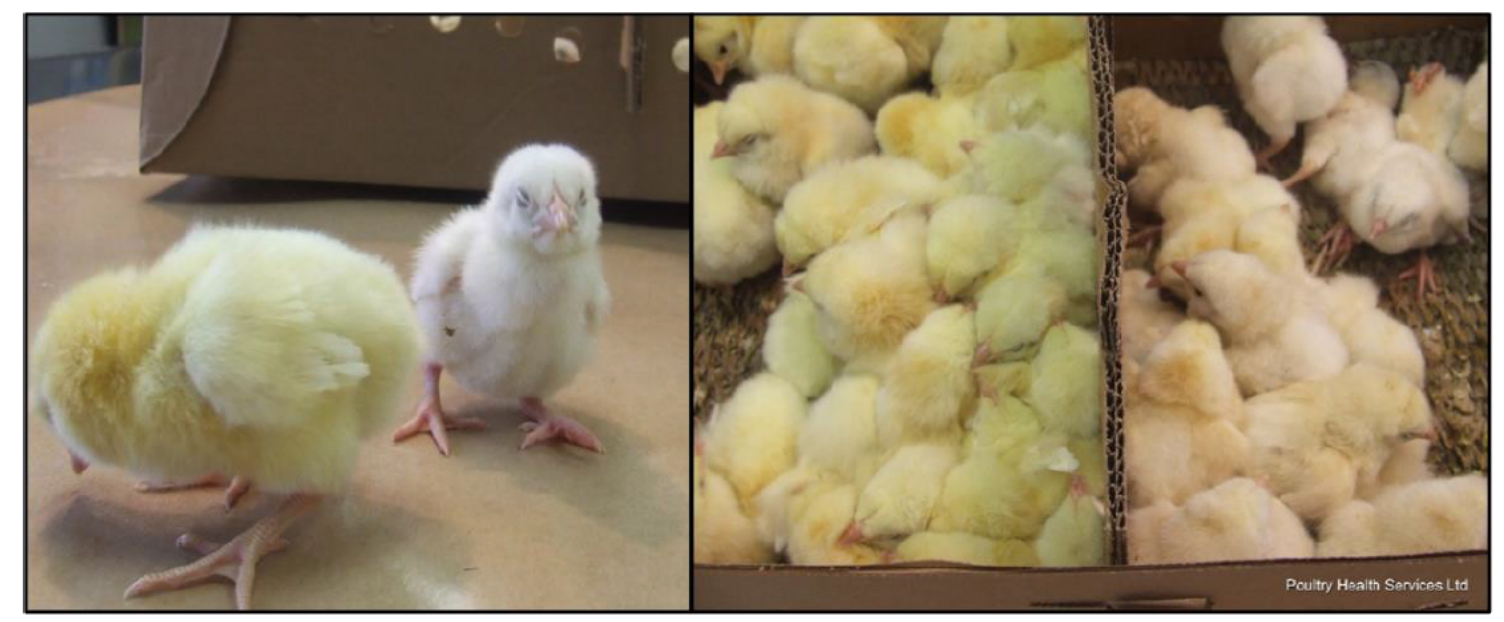

(a)

(b)

Figure 1. Hatching of normal (yellow) and affected (white) chicks. Progenitor broiler breeders had a drop in production, and low hatchability (case 14-1235). Apparently normal chick on the left and an affected "white chick" on the right in (a). Chick box after quality check containing apparently normal chicks on the left, and affected chicks on the right (b).

In 14 of the 17 samples tested, we were able to isolate CAstV in CEL (Table 1). We speculate that the other three samples were not able to be isolated in CEL due to low amount of initial virus (high $\mathrm{Ct}$ value) or lack of viable virus.

Under microscopic examination of livers obtained from clinical cases (Figure 2c,d), affected livers showed mild to severe biliary proliferation with periportal stores of immature granulocytes. Bile ducts usually lined with hyperplastic epithelium and many are dilated, containing necrotic heterophils and eosinophilic debris. It is common to find acute peribiliary inflammation with accumulation of necrotic heterophils and accumulations of orange/eosinophilic fluid compatible with bile in the bile ducts and surrounding tissues (Figure 2c-black arrows). The same fluid can be found pooling in canaliculi (Figure 2c-blue arrows), with variably sized foci of acute periportal hepatic necrosis with mild hemorrhage and small periportal aggregates of immature heterophils. It is thought that this trapped bile is the responsible of the characteristic green color of some affected livers seen in WCS cases. 


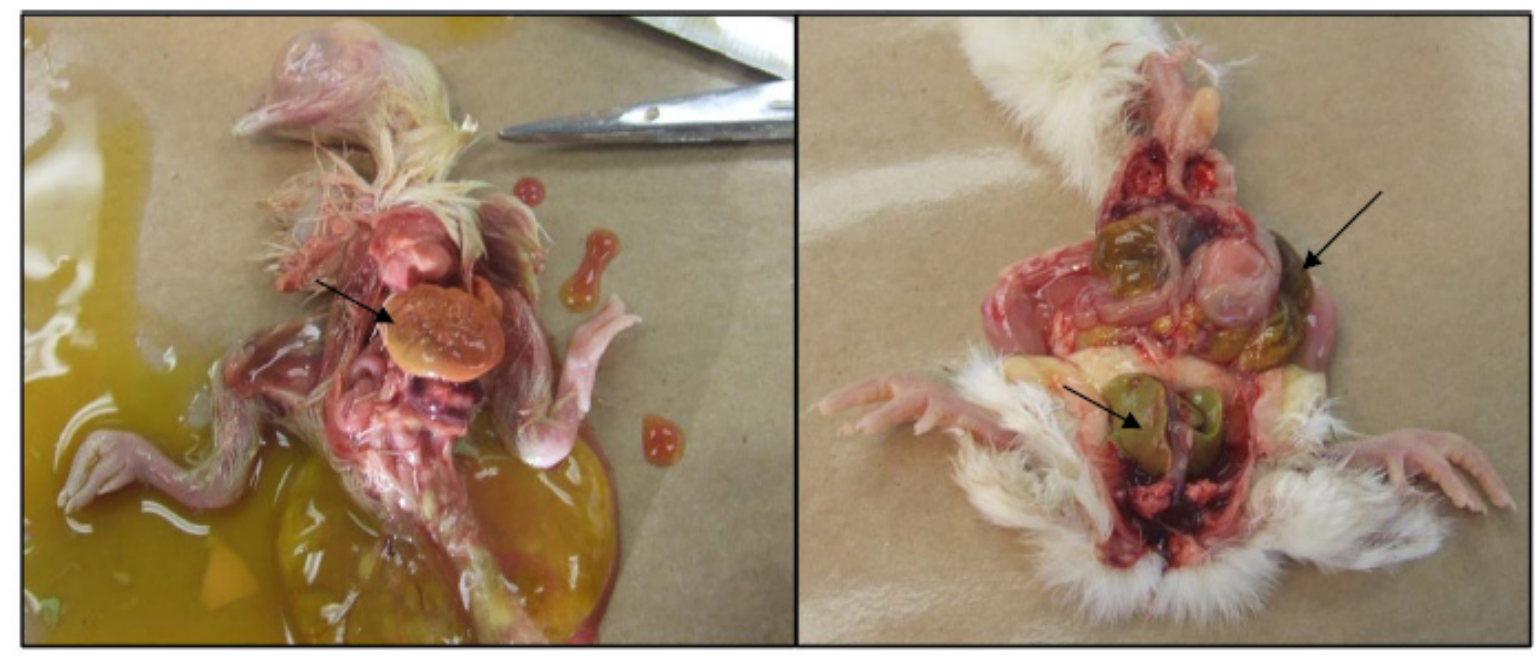

(a)

(b)

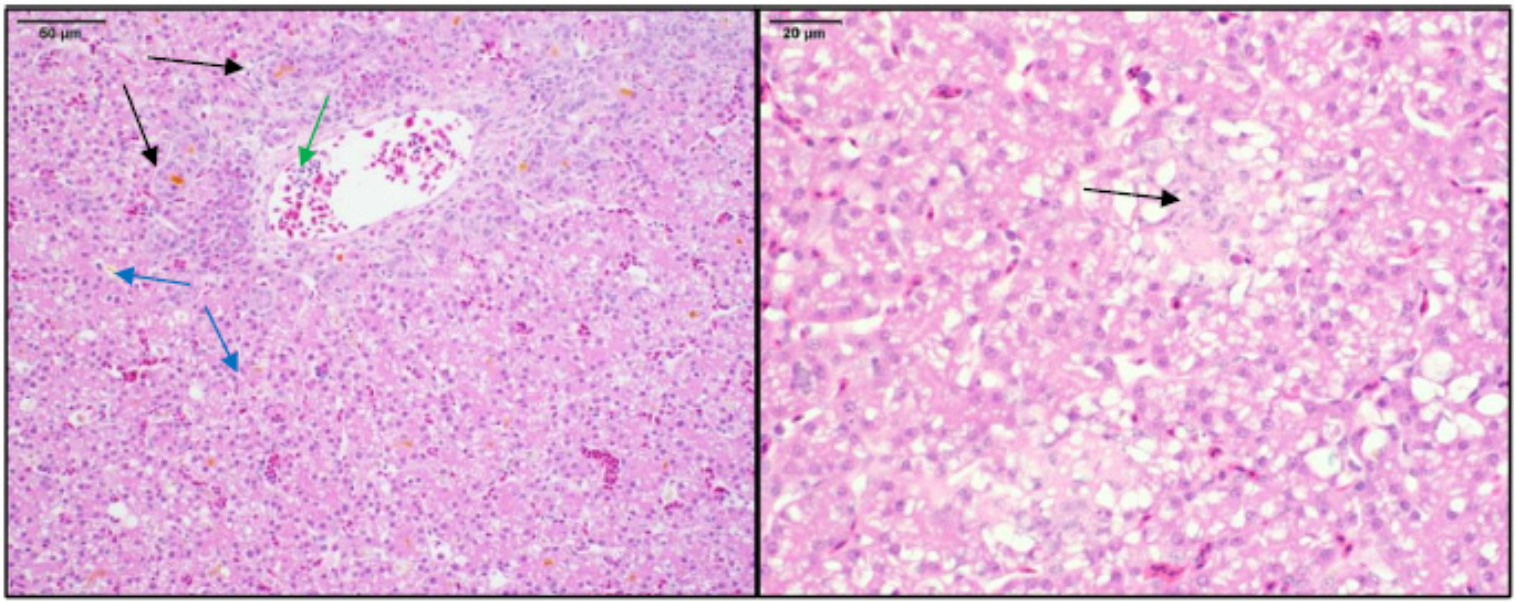

(c)

(d)

Figure 2. Post-mortem examination on dead-in-shell embryos and culls of case 15-1262a, and histopathology of cases 14-1235a; and 15-1262a, respectively. Dead-in-shell embryo with enlarged firm green livers in (a). Day-old culled chick with white plumage showing enlarged firm green liver and unabsorbed yolk-sac contents with visible green discoloration in (b). CAstV microphotographs of histopathological liver lesions on white chick syndrome (WCS) clinical cases. Case 14-1235a shows in $20 \times(c)$, proliferating bile ducts in black arrows, bile in canalicular lumens in blue arrows, and heterophils and macrophages in the portal vain in the green arrow. Case 15-1262a (d) shows in 40× one small foci of acute hepatic necrosis (black arrow).

\subsection{Whole Genome Sequencing}

The complete genome sequences of CAstV isolates $(n=14)$ with their corresponding genome size are shown in Supplementary Table S1. Other complete sequences $(n=10)$ were included in the analysis and genotype, phylogenetic tree constructed, and publication from which they were obtained are shown in Table 2. For all samples, the full coding sequence was obtained, and most of the $5^{\prime}$ and $3^{\prime}$ non-coding regions were also obtained by Bioinformatic resequencing analysis performed with CLC Genomics Workbench v 12.0.2 (Qiagen, Valencia, CA, USA). In the present study, whole genome phylogenetic analysis was performed on 24 complete $\mathrm{CAstV}$ sequences, showed that all $14 \mathrm{CAstV}$ sequences circulating in Western Canada clustered with CAstV from United States (US): CC_CkAstV/US/2014, and CkP5/US/2016. The same clustering corresponded to their ORF2 genotype (Figure 3). All sequences analyzed in this study were included in a separate 
cluster within Genotype B, different from Aiii (G059/PL/2014); Bi (Chinese strains: CZ1701/CN/2017; HBLP717-1/CN/2018; NJ1701/CN/2017; and GDYHTJ718-6/CN/2018); Bii (US strains: GA2011/US/2011; 4175/US/2011); Biii (Indian strain: ANAND/IN/2016); and in the same cluster as US strains CkP5/US/2016; and CC_CkAstV/US/2014. To our knowledge, no complete CAstV genome characterized as genotype Biv has been uploaded to GenBank. The following findings were observed in the whole genome alignment: (1) Consensus sequence with 7809 nucleotides (nt), with ungapped lengths of 24 sequences: Mean = 7479.6 nt, Minimum = 7008 nt, Maximum = 7603 nt, Std Dev = 108.45 nt; (2) 3,879 nt identical sites with $3930 \mathrm{nt}$ (50\%); (3) 86.1\% nt pairwise identity; and (4) 204 nt gaps with 43 of those gaps in coding sequences (ORF1a, ORF1b, and ORF2). These changes resulted into 917 non-synonymous mutations in ORF1a, ORF1b, and ORF2. Phylogenetic trees (Figures 3 and 4) showed Nucleotide RAxML phylogenetic tree of complete CAstV sequences clustered in a similar way as the aa RaxML based phylogenetic tree of ORF2 CAstV sequences, but these two phylogenetic trees (Figures 3 and 4) clustered differently as aa RAxML phylogenetic trees of ORF1a, and ORF1b (Supplement Figures S1 and S2).

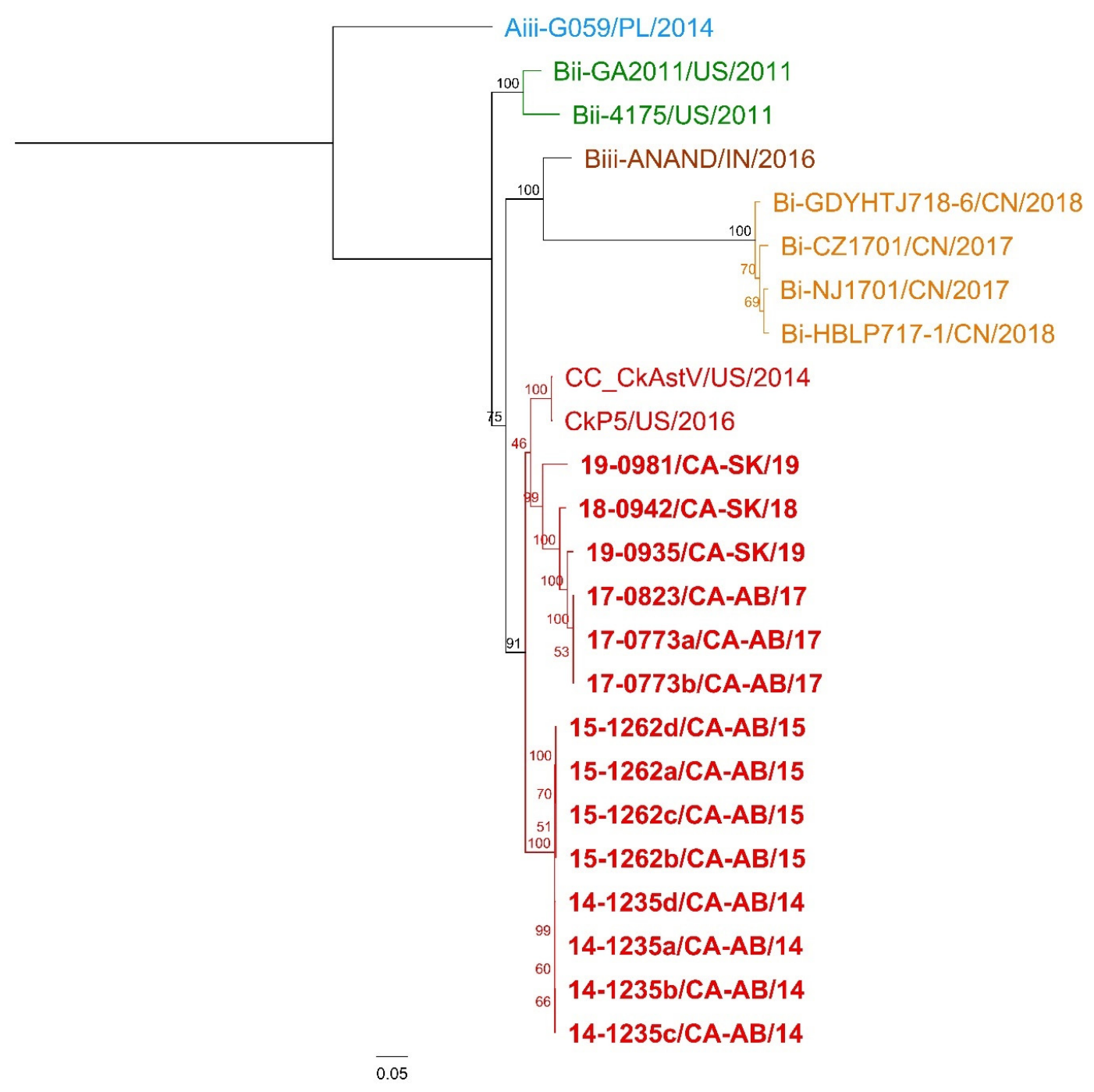

Figure 3. Nucleotide ML phylogenetic tree of complete CAstV sequences. Different colors indicate different genotypes according to ORF2 analysis described in Smyth et al. 2017 (i.e., Aiii, Bi, Bii, Biii, and Biv in red) [5]. The included sequences are described in Supplementary Table S1. Canadian sequences are in bold. 


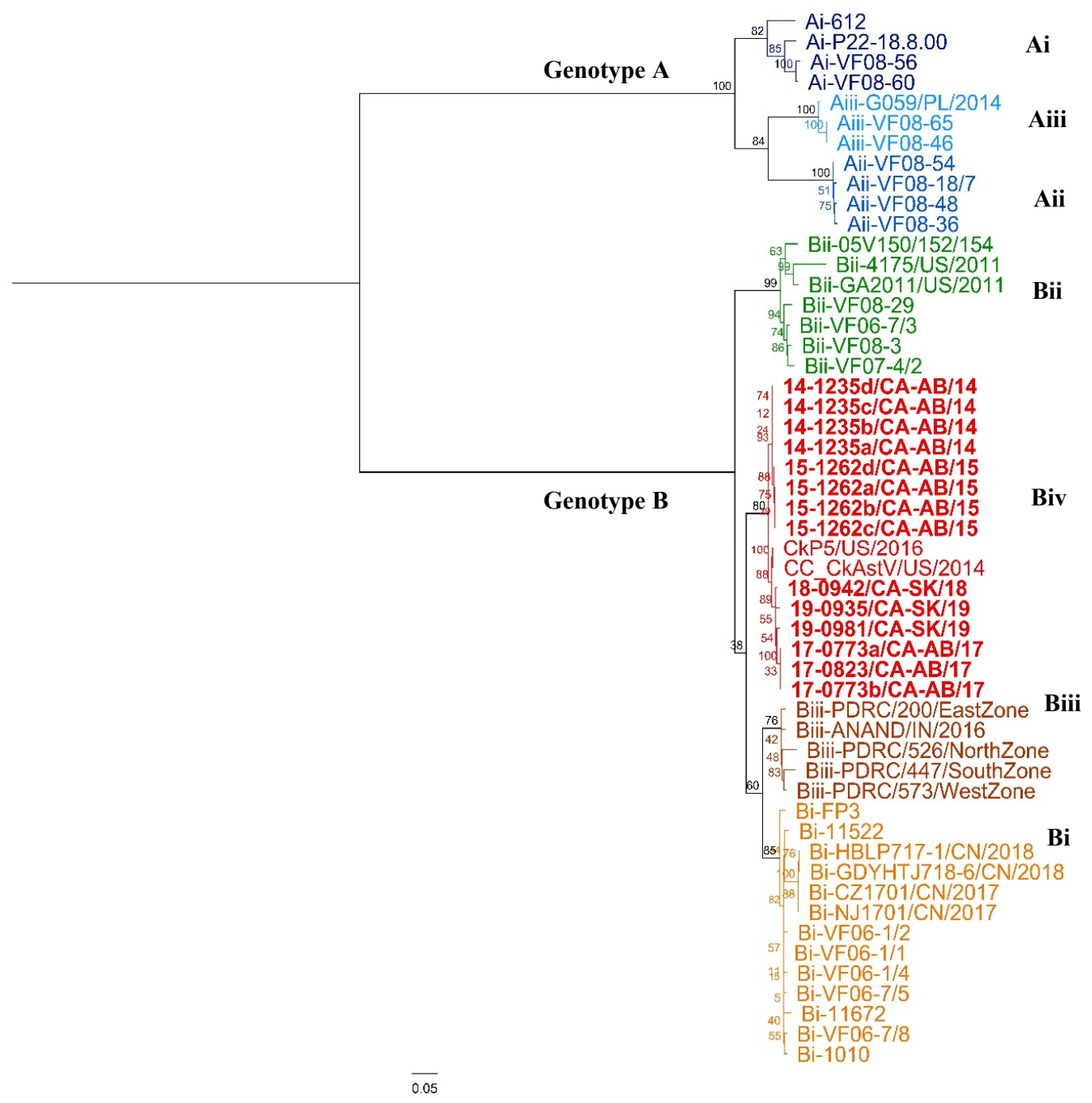

Figure 4. Amino acid ML phylogenetic tree of 52 ORF2 CAstV sequences. Different colors indicate different genotypes according to ORF2 analysis described by Smyth 2017 [5]. The included sequences are described in Supplementary Table S1.

\subsection{ORF1a}

A total of $1274 \mathrm{nt}$ mutations, and $9 \mathrm{nt}$ gaps were identified in the ORF1a gene, rendering 246 aa changes and 3 gaps in a consensus sequence of 1142 aa (21.5\%) out of 24 sequences (Supplementary Table S1) $[2,15,50,51]$. Out of the three coding regions in CAstV, ORF1a was the one with the lowest aa variation. Many of the non-synonymous mutations present were specific to genotypes A or B; thus, the ORF1a phylogenetic tree in Supplementary Figure S1, shows that genotypes A and B clustered separately. However, unlike Figure 3 (whole genome phylogenetic tree), and Figure 4 (ORF2 phylogenetic tree), not all sequences within ORF2 genotype B clustered according to their sub-genotype. For instance, sequence Bii-4175/US/2011 clustered near Biv sequences CkP5/US/2016, and CC_CkAst/US/2014; and sequences Bii-GA2011/US/2011 and Biii-ANAND/IN/2016 close to Canadian isolates obtained in this research during 2014, and 2015 (Supplementary Figure S1).

\subsection{ORF1b}

A total of $1563 \mathrm{nt}$ mutations, and $3 \mathrm{nt}$ gaps were identified in the ORF1b gene, rendering 139 aa changes, and 3 aa gaps in a consensus sequence of 521aa (26.7\%) out of 24 sequences (Supplementary Table S1) $[2,15,50,51]$. The phylogenetic tree in Supplementary Figure S2 shows that genotypes 
A and B clustered separately. However, unlike Figure 3 (whole genome phylogenetic tree), and Figure 4 (ORF2 phylogenetic tree), and similarly to Supplementary Figure S1 (ORF1a phylogenetic tree) not all sequences within ORF2 genotype B clustered according to their sub-genotype. For instance, sequence Bii-4175/US/2011 clustered in between Canadian CAstV isolated in 2014/2015 and 2017/2018/2019; and Bii-GA2011/US/2011 clustered near Biv sequences CkP5/US/2016, and CC_CkAst/US/2014. This, in contrast with ORF1a tree (Supplementary Figure S1), and Biii-ANAND/IN/2016 close to Canadian isolates obtained in 2014, and 2015 (Supplementary Figure S1).

\subsection{Genotyping and Comparison of ORF2}

Comparison between all previously published ORF2 sequences in research papers $(n=14)$ (Table 2) $[2,5,15,50,51]$, GenBank, and those obtained in the current work $(n=38 ; 52$ sequences in total), showed the presence of several unique and shared mutations in $1728 \mathrm{nt}$ in a consensus sequence of $2267 \mathrm{nt}(76.2 \%)$ with $49 \mathrm{nt}$ gaps in a consensus sequence. These mutations translated into 591 aa non-synonymous mutations in a 788 aa-length with 30 aa gaps in a consensus protein sequence. Out of the three coding regions in CAstV, ORF2 was the one with the highest aa variation.

The 14 Western Canadian isolates together with CkP5/US/2016 and CC_CkAstV/US/2014 clustered into a subgroup different from all published reference strains analyzed (Figure 4). As no representative sequence genotyped as Biv CAstV antigenic group was uploaded to GenBank, the authors contacted Dr. Victoria Smyth from the Agri-Food and Bioscience Institute in Belfast, United Kingdom, who confirmed that reference strains CkP5/US/2016, CC_CkAst/US/2014, and 14-1235a were classified within the Biv subcluster and share $97.8-98.8 \%$ aa similarity with VF11-71, a Canadian isolate obtained from a case of WCS, and 95.0-96.7\% aa similarity with WCS European sequences VF10-26, and VF11-66 [5,52]. Amino acid sequence identity between Western Canada sequences was of 96.88-100\%; and when compared with US sequences corresponding to Biv group, aa sequence identity varied from 97.97 to $98.51 \%$. Other aa sequence identities within groups were: Group A-75.83-100\%: Ai-89.72-99.03\%; Aii-99.03-99.45\%; Aiii-98.33-100\%; Group B-77.05-100\%; Bi-95.66-100\%; Bii-88.43-98.79\%; Biii-94.99-98.37\%; and Biv-96.88-100\%. Groups A and B were dissimilar and only shared $33.53-38.93 \%$ of aa identity.

\subsection{Recombination Analysis}

There was a total of 36 recombination events found by RDP5 software using the full exploratory recombination scan function, but only 12 were supported by at least 6 of 7 algorithms, as indicated in the Material and Methods section on 24 complete CAstV genomes. Table 3 shows a summary of those 12 events, the recombinant and major parent (P1) and minor parent (P2), the number of recombination methods supporting the events, $p$-value ranges, and most likely position of breaking points. 
Table 3. Details on Recombination Events detected by at least 6 methods on alignment of 24-CAstV complete sequences.

\begin{tabular}{|c|c|c|c|c|}
\hline Event & $\begin{array}{c}\text { Recombinant (R)\& } \\
\text { Parents (P1, P2) }\end{array}$ & No. of Methods & $P$-Value Range & $\begin{array}{c}\text { Position of } \\
\text { Breaking Points }\end{array}$ \\
\hline 3 & $\begin{array}{l}\text { (R)- 19-0981/CA-SK/19 } \\
\text { P1- Bii-GA2011/US/2011 } \\
\text { P2- 19-0935/CA-SK/19 }\end{array}$ & 6 & $\begin{array}{c}1.811 \times 10^{-28}-1.695 \\
\times 10^{-90}\end{array}$ & $\begin{array}{c}\text { ORF2 } \\
\text { Start: } 5090 \mathrm{nt} \\
\text { End: } 7750 \mathrm{nt}\end{array}$ \\
\hline 4 & $\begin{array}{c}\text { (R)- 19-0981/CA-SK/19 } \\
\text { P1- Bii-4175/US/2011 } \\
\text { P2- 19-0935/CA-SK/19 }\end{array}$ & 6 & $\begin{array}{c}5.440 \times 10^{-11}-8.389 \\
\times 10^{-86}\end{array}$ & $\begin{array}{c}\text { ORF2 } \\
\text { Start: } 5088 \mathrm{nt} \\
\text { End: } 84 \mathrm{nt}\end{array}$ \\
\hline 5 & $\begin{array}{l}\text { (R)- Biii-ANAND/IN/2016 } \\
\text { P1- Bi-HBLP717-1/CN/2018 } \\
\text { P2- 15-1262b/CA-AB/15 }\end{array}$ & 7 & $\begin{array}{c}7.876 \times 10^{-06}-1.566 \\
\times 10^{-86}\end{array}$ & $\begin{array}{l}\text { ORf2 } \\
\text { Start: } 7770 \mathrm{nt} \\
\text { End: } 5470 \mathrm{nt}\end{array}$ \\
\hline 6 & $\begin{array}{c}\text { (R)- Bi-GDYHTJ718-6/CN/2018 } \\
\text { P1- Bi-CZ1701/CN/2017 } \\
\text { P2- CC_CkAstV/US/2014 }\end{array}$ & 6 & $\begin{array}{c}1.501 \times 10^{-07}-2.149 \\
\times 10^{-32}\end{array}$ & $\begin{array}{l}\text { Start: } 7606 \mathrm{nt} \\
\text { End: } 130 \mathrm{nt}\end{array}$ \\
\hline 7 & $\begin{array}{l}\text { (R)- 18-0942/CA-SK/18 } \\
\text { P1- 19-0981/CA-SK/19 } \\
\text { P2- 19-0935/CA-SK/19 }\end{array}$ & 7 & $\begin{array}{c}5.222 \times 10^{-11}-4.321 \\
\times 10^{-46 *}\end{array}$ & $\begin{array}{l}\text { ORF1a-ORF1b } \\
\text { Start: } 1507 \mathrm{nt} \\
\text { End: } 5332 \mathrm{nt}\end{array}$ \\
\hline 8 & $\begin{array}{c}\text { (R)- 18-0942/CA-SK/18 } \\
\text { P1- Bi-GDYHTJ718-6/CN/2018 } \\
\text { P2- Bii-GA2011/US/2011 }\end{array}$ & 6 & $\begin{array}{c}1.613 \times 10^{-04}-1.910 \\
\times 10^{-14 * *}\end{array}$ & $\begin{array}{c}\text { ORF2 } \\
\text { Start: } \sim 7294 \mathrm{nt} \\
\text { End: } 5620 \mathrm{nt}\end{array}$ \\
\hline 9 & $\begin{array}{l}\text { (R)- 19-0935/CA-SK/19 } \\
\text { P1- 17-0773a/CA-AB/17 } \\
\text { P2- 19-0981/CA-SK/19 }\end{array}$ & 6 & $\begin{array}{c}1.129 \times 10^{-03}-1.876 \\
\times 10^{-13}\end{array}$ & $\begin{array}{c}\text { ORF2 } \\
\text { Start: } 5098 \mathrm{nt} \\
\text { End: } 7573 \mathrm{nt}\end{array}$ \\
\hline 10 & $\begin{array}{l}\text { (R)- 19-0981/CA-SK/19 } \\
\text { P1- 15-1262b/CA-AB/15 } \\
\text { P2- 17-0773a/CA-AB/17 }\end{array}$ & 6 & $\begin{aligned} 3.210 & \times 10^{-07}-1.015 \\
& \times 10^{-23}\end{aligned}$ & $\begin{array}{l}\text { ORF2 } \\
\text { Start: } 5133 \mathrm{nt} \\
\text { End: } 804 \mathrm{nt}\end{array}$ \\
\hline 12 & $\begin{array}{c}\text { (R)- CC_CkAstV/US/2014 } \\
\text { P1- 14-1235d/CA-AB/14 } \\
\text { P2- Bii-4175/US/2011 }\end{array}$ & 6 & $\begin{array}{c}1.171 \times 10^{-05}-3.033 \\
\times 10^{-23}\end{array}$ & $\begin{array}{l}\text { ORF1a-ORF1b } \\
\text { Start: } 2818 \mathrm{nt} \\
\text { End: } \sim 4929 \mathrm{nt}\end{array}$ \\
\hline 13 & $\begin{array}{l}\text { (R)- Bii-GA2011/US/2011 } \\
\text { P1- Bii-4175/US/2011 } \\
\text { P2- 18-0942/CA-SK/18 }\end{array}$ & 6 & $\begin{aligned} 1.630 & \times 10^{-02}-3.383 \\
& \times 10^{-09}\end{aligned}$ & $\begin{array}{l}\text { ORF1a-ORF1b } \\
\text { Start: } 2408 \mathrm{nt} \\
\text { End: } 4012 \mathrm{nt}\end{array}$ \\
\hline 14 & $\begin{array}{c}\text { (R)- Bii-GA2011/US/2011 } \\
\text { P1- 18-0942/CA-SK/18 } \\
\text { P2- Biii-ANAND/IN/2016 }\end{array}$ & 7 & $\begin{array}{c}1.088 \times 10^{-03}-9.808 \\
\times 10^{-08}\end{array}$ & $\begin{array}{c}\text { ORF1a } \\
\text { Start: } 1912 \mathrm{nt} \\
\text { End: } \sim 2407 \mathrm{nt}\end{array}$ \\
\hline 15 & $\begin{array}{l}\text { (R)- Bii-GA2011/US/2011 } \\
\text { P1- 19-0981/CA-SK/19 } \\
\text { P2- CC_CkAstV/US/2014 }\end{array}$ & 7 & $\begin{array}{c}1.167 \times 10^{-03}-3.633 \\
\times 10^{-08}\end{array}$ & $\begin{array}{c}\text { ORF1a } \\
\text { Start: } 1000 \mathrm{nt} \\
\text { End: } 1327 \mathrm{nt}\end{array}$ \\
\hline
\end{tabular}

${ }^{*}$ Beginning breakpoint outside of confidence interval. ${ }^{* *}$ Recombination signal may be attributable to a process other than recombination. Unknown breaking point, approximate location noted.

In addition, ML phylogenetic trees were generated based on each event breakpoints to evidence relations between recombinant and parental sequences (Supplementary Figure S3). Putative recombinant sequences Biv-19-0981/CA-SK/19; Biii-ANAND/IN/2016; Bi-GDYHTJ718-6/CN/2018; Biv-18-0942/CA-SK/18; Biv-19-0935/CA-SK/19; Biv-CC_CkAstV/US/2014; and Bii-GA2011/US/2011 were further analyzed using the Bootscan analysis within the Simplot program (Figure 5). Based on all these three previous analyses, the evidence suggests the presence of seven recombinant sequences (Table 4). 


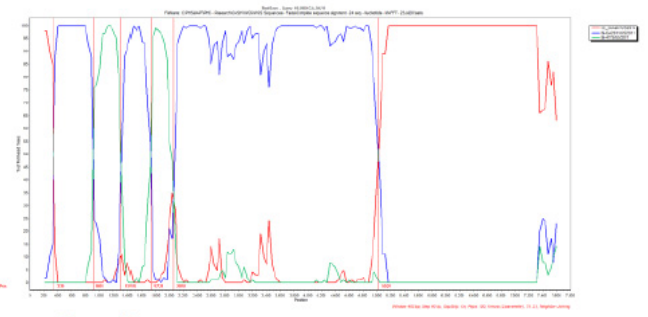

Query Sequence 19-0981/CA-SK/19

(a)

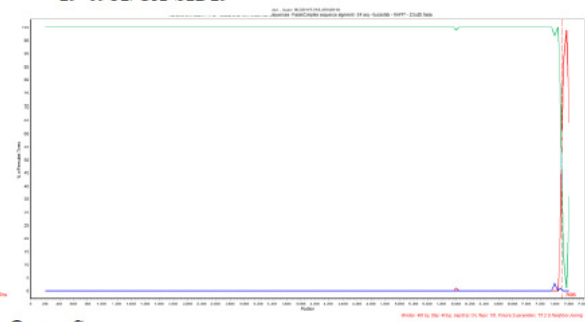

Query Sequence Bi-GDYHTJ718-6/CN/2018

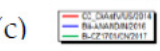

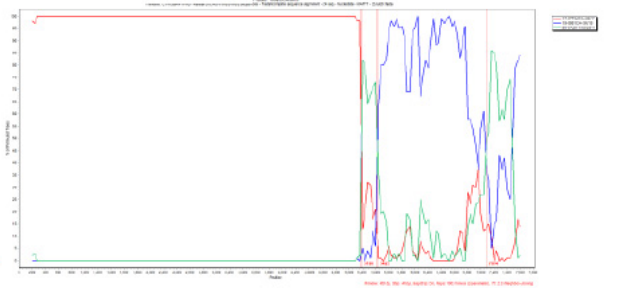

Query Sequence 19-0935/CA-SK/19

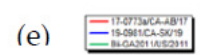

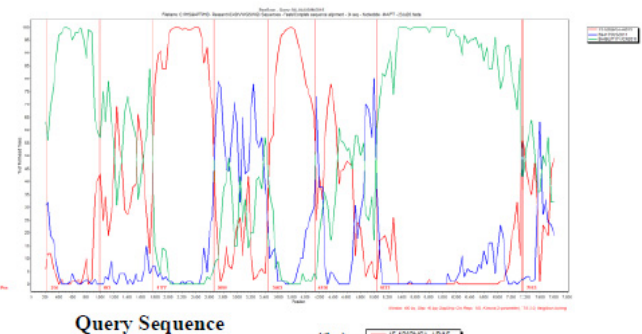

Query Sequence

Biii-ANAND/IN/2016

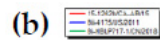
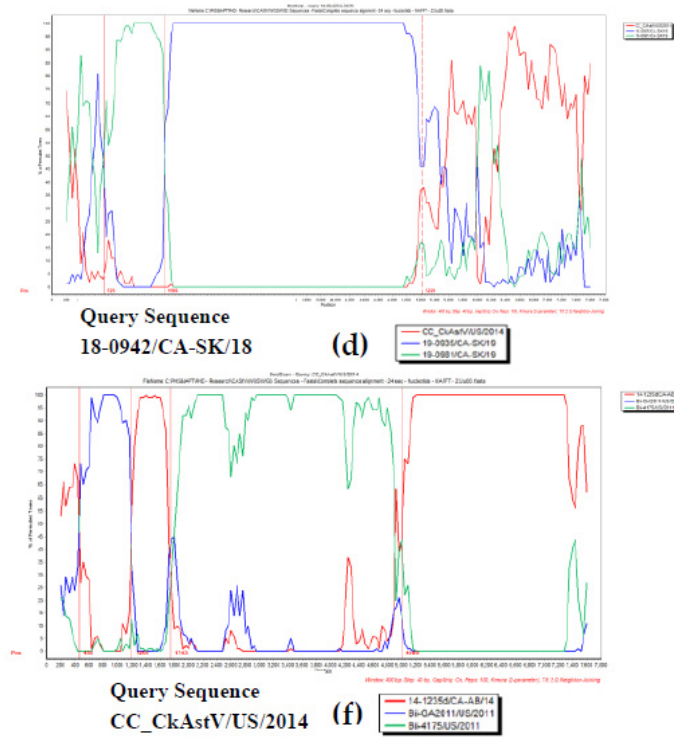

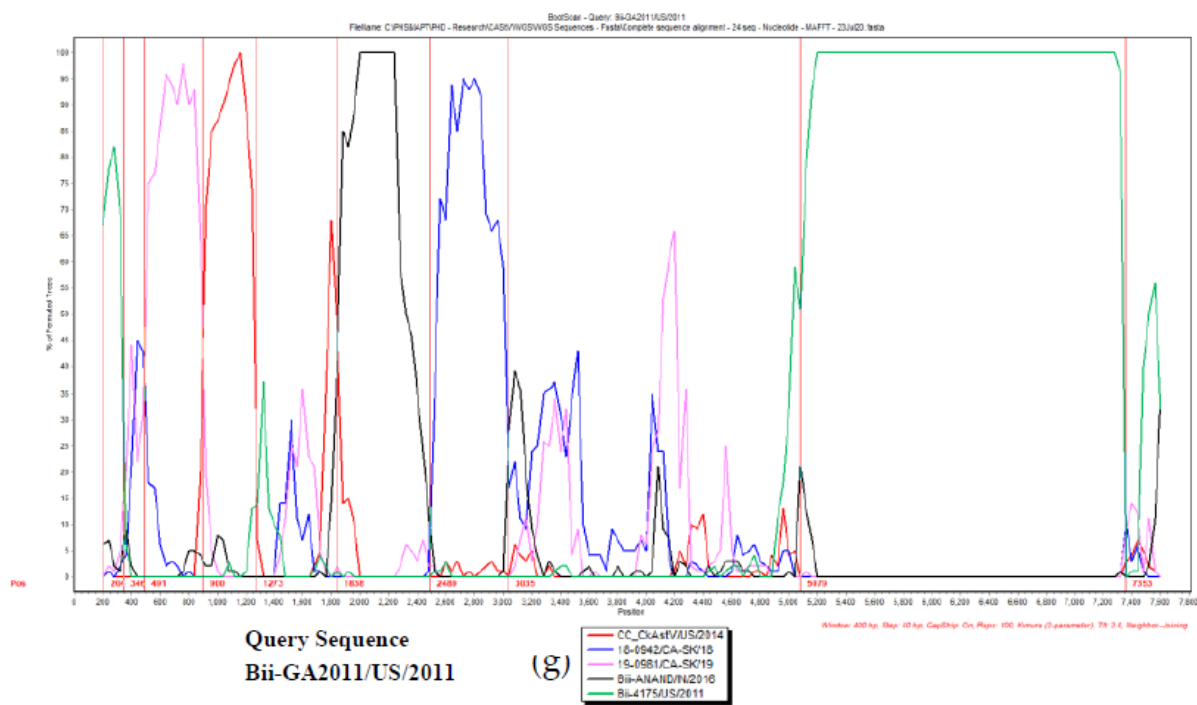

Figure 5. Bootscan analysis of recombinant CAstV sequences for confirming recombination was performed using Simplot program v3.5.1. Each analysis considers different parent sequences (different colors) plotted in a graph considering in the vertical-axis Percentage of permuted trees, and on the horizontal axis, position on the genome of the query sequence. Recombinant CAstV query sequences are 19-0981/CA-SK/19 (Supplementary Figure S3a); Biii-ANAND/IN/2016 (Supplementary Figure S3b); Bi-GDYHTJ718-6/CN/2018 (Supplementary Figure S3c); 18-0942/CA-SK/18 (Supplementary Figure S3d); 19-0935/CA-SK/19 (Supplementary Figure S3e); CC_CkAstV/US/2014 (Supplementary Figure S3f); and Bii-GA2011/US/2011 (Supplementary Figure S3g). 
Table 4. CAstV recombinant sequences and parents/parent-like sequences detected by 6 recombination methods in RDP5, ML phylogenetic trees, and Bootscan analysis in SimPlot software.

\begin{tabular}{|c|c|c|c|c|}
\hline$\#$ & $\begin{array}{l}\text { Recombinant } \\
\text { Genotype }\end{array}$ & Recombinant Sequence & Parental Genotype & Parent Sequences \\
\hline \multirow{3}{*}{1} & \multirow{3}{*}{ Biv } & \multirow{3}{*}{ 19-0981/CA-SK/19 } & Biv & CC_CkAstV/US/2014 \\
\hline & & & Bii & GA2011/US/2011 \\
\hline & & & Bii & 4175/US/2011 \\
\hline \multirow{2}{*}{2} & \multirow{2}{*}{ Biii } & \multirow{2}{*}{ ANAND/IN/2016 } & $\mathrm{Bi}$ & HBLP717-1/CN/2018 \\
\hline & & & Biv & $15-1262 \mathrm{~b} / \mathrm{CA}-\mathrm{AB} / 15$ \\
\hline \multirow{2}{*}{3} & \multirow{2}{*}{$\mathrm{Bi}$} & \multirow{2}{*}{ GDYHTJ718-6/CN/2018 } & $\mathrm{Bi}$ & CZ1701/CN/2017 \\
\hline & & & Biv & CC_CkAstV/US/2014 \\
\hline \multirow{2}{*}{4} & \multirow{2}{*}{ Biv } & \multirow{2}{*}{ 18-0942/CA-SK/18 } & Biv & 19-0981/CA-SK/19 \\
\hline & & & Biv & 19-0935/CA-SK/19 \\
\hline \multirow{2}{*}{5} & \multirow{2}{*}{ Biv } & \multirow{2}{*}{ Biv-19-0935/CA-SK/19 } & Biv & 17-0773a/CA-AB/17 \\
\hline & & & Biv & 19-0981/CA-SK/19 \\
\hline \multirow{3}{*}{6} & \multirow{3}{*}{ Biv } & \multirow{3}{*}{ CC_CkAstV/US/2014 } & Biv & 14-1235d/CA-AB/14, \\
\hline & & & Bii & GA2011/US/2011 \\
\hline & & & Bii & 4175/US/2011 \\
\hline \multirow{5}{*}{7} & \multirow{5}{*}{ Bii } & \multirow{5}{*}{ GA2011/US/2011 } & Bii & 4175/US/2011, \\
\hline & & & Biv & 19-0981/CA-SK/19, \\
\hline & & & Biv & CC_CkAstV/US/2014, \\
\hline & & & Biii & ANAND/IN/2016 \\
\hline & & & Biv & 18-0942/CA-SK/18 \\
\hline
\end{tabular}

\section{Discussion}

For the last 30 years, WCS has been increasingly gaining relevance in North America and Europe $[5,21,53-56]$. Thus, it is crucial to understand the antigenic variation of the field challenge in our production systems in order to implement better control strategies. The objective of the present study was to molecularly characterize complete sequences of CAstV isolates causing WCS in Western Canada since 2014. The tissue culture level of passage of the isolates used in this study was only of three passages, which lowers the possibility of genetic adaptations to in vitro system and not originally found in the isolate. This is supported by one study and two regulatory agencies. The study, published in 2008, examined the highly variable S protein of infectious bronchitis virus (IBV), in 8 strains for up to 10 passages in vitro (egg passage); in this study, six strains had no changes, two had two non-synonymous changes, and only one had non-synonymous change [57]. Furthermore, regulatory agencies in Europe [58] and US [59] consider that the production of a licensed commercial vaccine should occur within five passages from the virus master seed as to warrant preservation of master seed characteristics based on internal testing. This is specified in case of the US regulation (9CFR) for the following poultry viral vaccines: avian encephalomyelitis, avian pox, infectious bronchitis, infectious laryngotracheitis, Newcastle disease, infectious bursal disease, and avian reo viral arthritis [59].

All $14 \mathrm{CAstV}$ sequences circulating in Western Canada clustered together with $\mathrm{CAstV}$ from the US: CC_CkAstV/US/2014, and CkP5/US/2016 in a sub-cluster within the B genotype. Interestingly, these US sequences are linked not to a WCS case but to an RSS case in broilers in the US, in which CC_CkAstV/Us/2014 corresponds to the isolation in Leghorn Male Hepathoma (LMH) cells and $\mathrm{CkP5} / \mathrm{US} / 2016$ to the fifth passage of this parent virus in chickens. This finding provides circumstantial 
evidence suggesting that some Canadian CAstV isolates obtained from WCS may have a RSS phenotype as well, which would have to be confirmed by animal studies. The genome organization (ORF1a, ORF1b, and ORF2) in the sequences described in this work were similar to the ones described previously [2,15,50,51]. Further classification of ORF2 coding sequence showed that, in agreement with the complete genome sequence analysis—but not with ORF1a, and ORF1b phylogenetic trees—all these sequences grouped together in a cluster within group B but independent from subgroups Bi, Bii, and Biii. Dr. Victoria Smyth from the Agri-Food and Bioscience Institute in Belfast, United Kingdom, kindly confirmed the location of representative strains within the subcluster Biv [5,52]. Thus, we considered all these Canadian sequences to be part of the subcluster Biv of CAstV, in agreement with other literature describing WCS phenotype hitherto in genotypes Biv and Aiii.

Other CAstV were detected circulating in Ontario, Canada, in recent years by Long et al. [4,22]. The 31 sequences described by Long et al. 2018 were originally classified as Bii group; however, this classification was based using only a partial ORF2 sequence consisting of $644 \mathrm{nt}$ of a $\sim 2269 \mathrm{nt}$ ORF2 consensus, which represents a $\sim 29 \%$ coverage. After analyzing the sequences from this study adjusted to $\sim 644 \mathrm{nt}$, many of the sequences classified as Biv and Biii groups, were classified as Bii (Supplementary Figures S4 and S5). Thus, it is possible that these Canadian sequences originally classified as Bii using a partial sequence analysis, would be classified as Biv or Biii genotypes when the entire ORF2 gene is analyzed. Furthermore, the authors identify that this issue poses a major risk for epidemiology: due to its high variability, laboratory identification needs to be uniform and rely on the analysis of the entire CAstV ORF2 gene prior to classification lest misclassify relevant outbreaks. This is particularly relevant when designing an autogenous vaccine program to contain such outbreaks.

Upon analyzing the data more closely, we observed that the ORF1a and ORF1b phylogenetic trees did not follow the cluster pattern observed on the whole genome and capsid protein (ORF2) phylogenetic trees, which is suggestive of a recombination event. Upon analyzing the sequences for recombination, we found 12 novel recombination events between viruses of the Genotype B groups, which suggests cocirculation of these different viruses in each point in their evolution. One third ( $n=4$, Events 7, 8, 9, and 10) of these events occurred between members of the same subcluster (Biv) producing a recombinant from the same subcluster Biv; while only one $(n=1$, Event 15$)$ produced a recombinant classified as a different subcluster (Bii). One half of these events ( $n=6$, Events 3, 4, 5, 6, 12 , and 13) involved one parent from a Biv group and another from Bii group, producing a variety of recombinant sequences (3 Biv, $1 \mathrm{Biii}, 1 \mathrm{Bi}$, and $1 \mathrm{Biv})$. Finally, one last event ( $n=1$, Event 14), considered one parent from subgroup Biv and another from Biii, producing a Bii recombinant.

Recombination events and mutations (i.e., large-scale, and small-scale) [60] are the main drivers of evolution in RNA viruses, and such events need to be considered and studied [61-64]. Although mutations can be analyzed by phylogenetic trees and used for tracking the spread of a virus sequence, these trees are built under the assumption of no recombination [65,66]. Thus, observations of high phylogenetic diversity, such as the one found in the present work, have been suggestive or indicative of recombination events $[67,68]$. Astrovirus recombination events have been described in poultry such as turkeys [69,70], ducks [71], and guinea fowl [72]. To the best of our knowledge, no recombination event has been described in chickens, albeit interspecies recombination has been suggested [50,51]. Events between astroviruses from the same species [73-75] or, more rarely, from different species, may cause a change in host or tissue tropism [76-78], and are more difficult to study when only partial genomes are collected, as many of the recombination events do not occur solely in the areas of genome that represent antigenic proteins [79]. Research in CAstV has been focused more on partial or complete analysis of coding sequences, as currently there are $310 \mathrm{CAstV}$ sequences available in GenBank, from which only $115(\sim 37 \%)$ correspond to complete or partial ORF2, $184(\sim 59 \%)$ to partial ORF1b, and only $11(\sim 3.5 \%)$ correspond to whole genome sequences. 


\section{Conclusions}

In the present study, we isolated and sequenced $14 \mathrm{CAstV}$ sequences from WCS cases. These were genotyped and classified within the novel Biv sub-cluster of $\mathrm{CAst} V$, according to the ORF2 (capsid) genotypic classification. The molecular characterization and phylogenetic studies suggested multiple past recombination events with several CAstV sequences, some of them from US origin, linked to RSS-cases. Our findings suggest that recombination events and the accumulation of point mutations may have contributed to the great genetic variation observed in $\mathrm{CAstV}$ and evidenced by the current seven antigenic sub-clusters described above. This is the first paper that describes recombination events in $\mathrm{CAst} V$ following analysis of complete $\mathrm{CAstV}$ sequences originated in Canada. Based on the information presented in this paper, whole genome sequencing methods are also a powerful and useful tool that allows better characterization of the CAstV strains circulating in the field.

Supplementary Materials: The following are available online at http://www.mdpi.com/1999-4915/12/10/1096/s1, Table S1: Genome Sizes of complete CAstV Sequences; Figure S1: Amino acid ML phylogenetic tree of ORF1a; Figure S2: Amino acid ML phylogenetic tree of ORF1b; Figure S3: Nucleotide ML phylogenetic analyses on CAstV on each of the recombination events described on Table 2; Figure S4: Amino acid ML phylogenetic tree of a total of 83 partial ORF2 CAstV sequences; Figure S5: Percentage heat map of amino acid identity obtained from ML phylogenetic tree described on Figure S4.

Author Contributions: Conceptualization, F.v.d.M., M.F.A.-C., and V.P.-T.; methodology, M.F.A.-C., D.M., T.I., and V.P.-T.; histopathology, M.B. and E.M.; software, F.v.d.M., C.P., C.A.G., and V.P.-T.; validation, F.v.d.M., M.F.A.-C., C.P., C.A.G., and V.P.-T.; formal analysis, F.v.d.M., C.P., C.A.G., and V.P.-T; investigation, D.M., T.I., and V.P.-T; resources, M.F.A.-C., D.M., T.I., and F.v.d.M.; data curation, F.v.d.M., C.P., C.A.G., and V.P.-T.; writing-original draft preparation, V.P.-T.; writing-review and editing, F.v.d.M, M.F.A.-C., and V.P.-T.; visualization, F.v.d.M., M.F.A.-C., and V.P.-T.; supervision, F.v.d.M., M.F.A.-C., T.I., and D.M.; project administration, M.F.A.-C., D.M., and T.I.; funding acquisition, M.F.A.-C., D.M., T.I., and V.P.-T. All authors have read and agreed to the published version of the manuscript.

Funding: This research was funded by Alberta Agriculture and Forestry, grant number 2018F162R. The APC was funded by Alberta Agriculture and Forestry, grant number 2018F162R. The graduate studies of V.P.T. are supported by Mitacs ${ }^{\circledR}$ Accelerate grant, Mitacs Inc., Canada grant received by F.A.C. (IT15623).

Acknowledgments: The authors also want to acknowledge the help and contribution of Brenda Ralston for her help as liaison within Institute of Applied Poultry Technologies (IAPT) and the laboratory located at Airdrie Agriculture Centre-Airdrie Centre (Airdrie, AB T4A 2K4, Canada). Special thanks to Holly Sellers, Poultry Diagnostic and Research Center, University of Georgia, USA for their continuing mentoring and help with this project.

Conflicts of Interest: The authors declare no conflict of interest.

\section{References}

1. Baxendale, W.; Mebatsion, T. The isolation and characterisation of astroviruses from chickens. Avian Pathol. 2004, 33, 364-370. [CrossRef] [PubMed]

2. Xue, J.; Han, T.; Zhao, Y.; Yang, H.; Zhang, G. Complete genome sequence and phylogenetic analysis of novel avastroviruses circulating in China from 2016 to 2018. Virus Res. 2020, 278, 197858. [CrossRef] [PubMed]

3. Saif, Y.M.; Guy, J.S.; Day, J.M.; Cattoli, G.; Hayhow, C.S. Viral Enteric Infections. In Diseases of Poultry; Swayne, D., Ed.; Elsevier: Cambridge, MA, USA, 2020; pp. 401-445.

4. Long, K.E.; Ouckama, R.M.; Weisz, A.; Brash, M.L.; Ojkic, D. White Chick Syndrome Associated with Chicken Astrovirus in Ontario, Canada. Avian Dis. 2018, 62, 247-258. [CrossRef] [PubMed]

5. Smyth, V.J. A Review of the Strain Diversity and Pathogenesis of Chicken Astrovirus. Viruses 2017, 9, 29. [CrossRef] [PubMed]

6. Sajewicz-Krukowska, J.; Pac, K.; Lisowska, A.; Minta, Z.; Kroliczewska, B.; Domanska-Blicharz, K. Astrovirus induced "white chicks" condition-field observation, virus detection and preliminary characterization. Avian Pathol. 2015, 1-36. [CrossRef]

7. Pantin-Jackwood, M.J.; Day, J.M.; Jackwood, M.W.; Spackman, E. Enteric viruses detected by molecular methods in commercial chicken and turkey flocks in the United States between 2005 and 2006. Avian Dis. 2008, 52, 235-244. [CrossRef]

8. McNulty, M.S.; Connor, T.J.; McNeilly, F.; McFerran, J.B. Biological characterisation of avian enteroviruses and enterovirus-like viruses. Avian Pathol. 1990, 19, 75-87. [CrossRef] 
9. Spackman, D.; Gough, R.E.; Collins, M.S.; Lanning, D. Isolation of an enterovirus-like agent from the meconium of dead-in-shell chicken embryos. Vet. Rec. 1984, 114, 216-218. [CrossRef]

10. Walker, P.J.; Siddell, S.G.; Lefkowitz, E.J.; Mushegian, A.R.; Dempsey, D.M.; Dutilh, B.E.; Harrach, B.; Harrison, R.L.; Hendrickson, R.C.; Junglen, S.; et al. Changes to virus taxonomy and the International Code of Virus Classification and Nomenclature ratified by the International Committee on Taxonomy of Viruses (2019). Arch. Virol. 2019, 164, 2417-2429. [CrossRef]

11. ICTV Astroviridae Taxonomy. Available online: https://talk.ictvonline.org/ictv-reports/ictv_9th_report/ positive-sense-rna-viruses-2011/w/posrna_viruses/247/astroviridae (accessed on 24 May 2020).

12. McNulty, M.S.; Curran, W.L.; McFerran, J.B. Detection of astroviruses in turkey faeces by direct electron microscopy. Vet. Rec. 1980, 106, 561. [CrossRef]

13. McNulty, M.S.; Curran, W.L.; Todd, D.; McFerran, J.B. Detection of viruses in avian faeces by direct electron microscopy. Avian Pathol. 1979, 8, 239-247. [CrossRef] [PubMed]

14. Mendez, E.; Arias, C.F. Astroviruses. In Fields Virology, 5th ed.; Knipe, D.M., Howley, P.M., Eds.; Lippincott Williams \& Wilkins: Philadelphia, PA, USA, 2013; pp. 609-628.

15. Kang, K.I.; Linnemann, E.; Icard, A.H.; Durairaj, V.; Mundt, E.; Sellers, H.S. Chicken astrovirus as an aetiological agent of runting-stunting syndrome in broiler chickens. J. Gen. Virol. 2018, 99, 512-524. [CrossRef] [PubMed]

16. Arias, C.F.; DuBois, R.M. The Astrovirus Capsid: A Review. Viruses 2017, 9, 15. [CrossRef] [PubMed]

17. Toh, Y.; Harper, J.; Dryden, K.A.; Yeager, M.; Arias, C.F.; Mendez, E.; Tao, Y.J. Crystal Structure of the Human Astrovirus Capsid Protein. J. Virol. 2016, 90, 9008-9017. [CrossRef]

18. Dryden, K.A.; Tihova, M.; Nowotny, N.; Matsui, S.M.; Mendez, E.; Yeager, M. Immature and mature human astrovirus: Structure, conformational changes, and similarities to hepatitis E virus. J. Mol. Biol. 2012, 422, 650-658. [CrossRef]

19. McNeilly, F.; Connor, T.J.; Calvert, V.M.; Smyth, J.A.; Curran, W.L.; Morley, A.J.; Thompson, D.; Singh, S.; McFerran, J.B.; Adair, B.M.; et al. Studies on a new enterovirus-like virus isolated from chickens. Avian Pathol. 1994, 23, 313-327. [CrossRef]

20. Bulbule, N.R.; Mandakhalikar, K.D.; Kapgate, S.S.; Deshmukh, V.V.; Schat, K.A.; Chawak, M.M. Role of chicken astrovirus as a causative agent of gout in commercial broilers in India. Avian Pathol. 2013, 42, 464-473. [CrossRef]

21. Smyth, V.; Trudgett, J.; Wylie, M.; Jewhurst, H.; Conway, B.; Welsh, M.; Kaukonen, E.; Perko-Makela, P. Chicken astrovirus detected in hatchability problems associated with "white chicks". Vet. Rec. 2013, 173, 403-404. [CrossRef]

22. Long, K.E.; Hastie, G.M.; Ojkic, D.; Brash, M.L. Economic Impacts of White Chick Syndrome in Ontario, Canada. Avian Dis. 2017, 61, 402-408. [CrossRef]

23. Smyth, V.J.; Jewhurst, H.L.; Wilkinson, D.S.; Adair, B.M.; Gordon, A.W.; Todd, D. Development and evaluation of real-time TaqMan(R) RT-PCR assays for the detection of avian nephritis virus and chicken astrovirus in chickens. Avian Pathol. 2010, 39, 467-474. [CrossRef]

24. Skibinska, A.; Lee, A.; Wylie, M.; Smyth, V.J.; Welsh, M.D.; Todd, D. Development of an indirect ELISA test for detecting antibodies to chicken astrovirus in chicken sera. Avian Pathol. 2015, 1-28.

25. Pantin-Jackwood, M.; Todd, D.; Koci, M.D. Avian Astroviruses. In Astrovirus Research: Essential Ideas, Everyday Impacts, Future Directions; Schultz-Cherry, S., Ed.; Springer: New York, NY, USA, 2013; pp. 151-180.

26. Smyth, V.J.; Todd, D.; Trudgett, J.; Lee, A.; Welsh, M.D. Capsid protein sequence diversity of chicken astrovirus. Avian Pathol. 2012, 41, 151-159. [CrossRef] [PubMed]

27. Deol, P.; Kattoor, J.J.; Sircar, S.; Ghosh, S.; Banyai, K.; Dhama, K.; Malik, Y.S. Avian Group D Rotaviruses: Structure, Epidemiology, Diagnosis, and Perspectives on Future Research Challenges. Pathogens 2017, 6, 53. [CrossRef] [PubMed]

28. Wlliams, S.M.; American Association of Avian Pathologists. A Laboratory Manual for the Isolation, Identification and Characterization of Avian Pathogens, 6th ed.; American Association of Avian Pathologists: Jacksonville, FL, USA, 2016; pp. 754-780.

29. Villegas, P. PDRC Laboratory Manual. In Georgia; T.U., o., Ed.; PDRC Laboratory: Athens, GA, USA, 2008.

30. Hess, M. Detection and differentiation of avian adenoviruses: A review. Avian Pathol. 2000, 29, $195-206$. [CrossRef] 
31. Jones, R.C.; Islam, M.R.; Kelly, D.F. Early pathogenesis of experimental reovirus infection in chickens. Avian Pathol. 1989, 18, 239-253. [CrossRef]

32. Kohn, F.S.; Henneman, S.A. Preparation of primary chicken embryo livers cells. PLoS ONE 1975, 14, e0225863. [CrossRef]

33. Schultz-Cherry, S. Astrovirus Infections. In Diseases of Poultry, 13th ed.; Swayne, D.E., Ed.; John Wiley \& Sons: Ames, IA, USA, 2013; pp. 391-395.

34. Katoh, K.; Misawa, K.; Kuma, K.; Miyata, T. MAFFT: A novel method for rapid multiple sequence alignment based on fast Fourier transform. Nucleic Acids Res. 2002, 30, 3059-3066. [CrossRef]

35. Katoh, K.; Standley, D.M. MAFFT multiple sequence alignment software version 7: Improvements in performance and usability. Mol. Biol. Evol. 2013, 30, 772-780. [CrossRef]

36. Stamatakis, A. RAxML version 8: A tool for phylogenetic analysis and post-analysis of large phylogenies. Bioinformatics 2014, 30, 1312-1313. [CrossRef]

37. Palomino-Tapia, V.; Mitevski, D.; Inglis, T.; van der Meer, F.; Abdul-Careem, M.F. Molecular characterization of emerging avian reovirus variants isolated from viral arthritis cases in Western Canada 2012-2017 based on partial sigma (sigma)C gene. Virology 2018, 522, 138-146. [CrossRef]

38. Abadi, S.; Azouri, D.; Pupko, T.; Mayrose, I. Model selection may not be a mandatory step for phylogeny reconstruction. Nat. Commun. 2019, 10, 934. [CrossRef] [PubMed]

39. Martin, D.P.; Posada, D.; Crandall, K.A.; Williamson, C. A modified bootscan algorithm for automated identification of recombinant sequences and recombination breakpoints. Aids Res. Hum. Retrovir. 2005, 21, 98-102. [CrossRef] [PubMed]

40. Martin, D.; Rybicki, E. RDP: Detection of recombination amongst aligned sequences. Bioinformatics 2000, 16, 562-563. [CrossRef] [PubMed]

41. Martin, D.P.; Murrell, B.; Golden, M.; Khoosal, A.; Muhire, B. RDP4: Detection and analysis of recombination patterns in virus genomes. Virus Evol. 2015, 1, vev003. [CrossRef]

42. Padidam, M.; Sawyer, S.; Fauquet, C.M. Possible emergence of new geminiviruses by frequent recombination. Virology 1999, 265, 218-225. [CrossRef]

43. Smith, J.M. Analyzing the mosaic structure of genes. J. Mol. Evol 1992, 34, 126-129. [CrossRef]

44. Posada, D.; Crandall, K.A. Evaluation of methods for detecting recombination from DNA sequences: Computer simulations. Proc. Natl. Acad. Sci. USA 2001, 98, 13757-13762. [CrossRef]

45. Gibbs, M.J.; Armstrong, J.S.; Gibbs, A.J. Sister-scanning: A Monte Carlo procedure for assessing signals in recombinant sequences. Bioinformatics 2000, 16, 573-582. [CrossRef]

46. Lam, H.M.; Ratmann, O.; Boni, M.F. Improved Algorithmic Complexity for the 3SEQ Recombination Detection Algorithm. Mol. Biol. Evol 2018, 35, 247-251. [CrossRef]

47. Lole, K.S.; Bollinger, R.C.; Paranjape, R.S.; Gadkari, D.; Kulkarni, S.S.; Novak, N.G.; Ingersoll, R.; Sheppard, H.W.; Ray, S.C. Full-length human immunodeficiency virus type 1 genomes from subtype C-infected seroconverters in India, with evidence of intersubtype recombination. J. Virol. 1999, 73, 152-160. [CrossRef]

48. Lee, S.W.; Markham, P.F.; Coppo, M.J.; Legione, A.R.; Markham, J.F.; Noormohammadi, A.H.; Browning, G.F.; Ficorilli, N.; Hartley, C.A.; Devlin, J.M. Attenuated vaccines can recombine to form virulent field viruses. Science 2012, 337, 188. [CrossRef] [PubMed]

49. Hassan, M.S.H.; Ojkic, D.; Coffin, C.S.; Cork, S.C.; van der Meer, F.; Abdul-Careem, M.F. Delmarva (DMV/1639) Infectious Bronchitis Virus (IBV) Variants Isolated in Eastern Canada Show Evidence of Recombination. Viruses 2019, 11, 1054. [CrossRef] [PubMed]

50. Patel, A.K.; Pandit, R.J.; Thakkar, J.R.; Hinsu, A.T.; Pandey, V.C.; Pal, J.K.; Prajapati, K.S.; Jakhesara, S.J.; Joshi, C.G. Complete genome sequence analysis of chicken astrovirus isolate from India. Vet. Res. Commun. 2017, 41, 67-75. [CrossRef]

51. Sajewicz-Krukowska, J.; Domanska-Blicharz, K. Nearly full-length genome sequence of a novel astrovirus isolated from chickens with 'white chicks' condition. Arch. Virol. 2016, 161, 2581-2587. [CrossRef] [PubMed]

52. Smyth, V.; (Avian Virology Unit of the Agri-Foods and Biosciences Institute (AFBI), Stoney Road, Stormont, Belfast, BT4 3SD, UK). Personal Communication, 2020.

53. Stayer, P.A.; Riley, E.G.; French, J.D.; Ferro, P.J.; Vanhooser, S.L.; Banda, A.; Baughman, B. Incursion and Recursion of "White Chicks" in U.S. Commercial Broiler Production. In Proceedings of the Annual Meeting of the American Veterinary Medical Association, San Antonio, TX, USA, 6-9 September 2016; p. 8. 
54. Brash, M.; Ojkic, A.D.; Ouckama, R.; Long, K.E.; Weisz, A. Etiologic Investigations into White chick Syndrome in Ontario. In Proceedings of the 65th Western Poultry Disease Conference, Vancouver, BC, Canada, 24-27 April 2016; p. 30.

55. Bishop, R. Poor hatchability and increased cull chicks associatedwith White Chick Syndrome as experienced in Eastern Canada in 2009. In Proceedings of the 59th Western Poultry Disease Conference, Vancouver, BC, Canada, 24-27 April 2010; p. 118.

56. Martin, E.; Brash, M.; Ojkic, A.D.; Ouckama, R.; Long, K.E. In Proceedings of the White chick syndrome in Ontario: Clinical features, pathology and viral etiology. Annual Meeting of the American Veterinary Medical Association, San Antonio, TX, USA, 6-9 August 2016; p. 53.

57. McKinley, E.T.; Hilt, D.A.; Jackwood, M.W. Avian coronavirus infectious bronchitis attenuated live vaccines undergo selection of subpopulations and mutations following vaccination. Vaccine 2008, 26, 1274-1284. [CrossRef] [PubMed]

58. European Union Committee for Medicinal Products for Veterinary Use (CVMP). Guideline on Data Requirements for the Replacement of Established Master Seeds (MS) Already Used in Authorised Immunological Veterinary Medicinal Products (IVMPs) by New Master Seed of the Same Origin Ed. 2010. Available online: https://www.ema.europa.eu/en/documents/scientific-guideline/guidelinedata-requirements-replacement-established-master-seeds-ms-already-used-authorised_en.pdf (accessed on 28 July 2020).

59. USDA, 2015, 9 CFR 113. Animal and Animal Products. Chapter I Animal and Plant Health Inspection Service, United States Department of Agriculture, Part 113. Code of Federal Regulations, USA. 2015; pp. 707-826. Available online: https://www.govinfo.gov/content/pkg/CFR-2015-title9-vol1/pdf/CFR-2015-title9-vol1.pdf (accessed on 28 July 2020).

60. Houle, D.; Kondrashov, A.S. Mutation. In Principles of Evolutionary Genetics; Syrawood Publishing House: New York, NY, USA, 2018.

61. Duffy, S. Why are RNA virus mutation rates so damn high? PLoS Biol. 2018, 16, e3000003. [CrossRef]

62. Sanjuan, R.; Domingo-Calap, P. Mechanisms of viral mutation. Cell Mol. Life Sci. 2016, 73, 4433-4448. [CrossRef]

63. Sanjuan, R.; Nebot, M.R.; Chirico, N.; Mansky, L.M.; Belshaw, R. Viral mutation rates. J. Virol. 2010, 84, 9733-9748. [CrossRef]

64. Malpica, J.M.; Fraile, A.; Moreno, I.; Obies, C.I.; Drake, J.W.; Garcia-Arenal, F. The rate and character of spontaneous mutation in an RNA virus. Genetics 2002, 162, 1505-1511.

65. Lanier, H.C.; Knowles, L.L. Is Recombination a Problem for Species-Tree Analyses? Syst. Biol. 2012, 61, 691-701. [CrossRef]

66. Posada, D. How does recombination affect phylogeny estimation? Trends Ecol. Evol. 2000, 15, 489-490. [CrossRef]

67. Bousalem, M.; Douzery, E.J.; Fargette, D. High genetic diversity, distant phylogenetic relationships and intraspecies recombination events among natural populations of Yam mosaic virus: A contribution to understanding potyvirus evolution. J. Gen. Virol. 2000, 81, 243-255. [CrossRef] [PubMed]

68. Worobey, M.; Holmes, E.C. Evolutionary aspects of recombination in RNA viruses. J. Gen. Virol. 1999, 80, 2535-2543. [CrossRef]

69. Strain, E.; Kelley, L.A.; Schultz-Cherry, S.; Muse, S.V.; Koci, M.D. Genomic analysis of closely related astroviruses. J. Virol. 2008, 82, 5099-5103. [CrossRef] [PubMed]

70. Pantin-Jackwood, M.J.; Spackman, E.; Woolcock, P.R. Molecular characterization and typing of chicken and turkey astroviruses circulating in the United States: Implications for diagnostics. Avian Dis. 2006, 50, 397-404. [CrossRef]

71. Liu, N.; Wang, F.; Shi, J.; Zheng, L.; Wang, X.; Zhang, D. Molecular characterization of a duck hepatitis virus 3-like astrovirus. Vet. Microbiol. 2014, 170, 39-47. [CrossRef]

72. De Battisti, C.; Salviato, A.; Jonassen, C.M.; Toffan, A.; Capua, I.; Cattoli, G. Genetic characterization of astroviruses detected in guinea fowl (Numida meleagris) reveals a distinct genotype and suggests cross-species transmission between turkey and guinea fowl. Arch. Virol. 2012, 157, 1329-1337. [CrossRef] 
73. Martella, V.; Pinto, P.; Tummolo, F.; De Grazia, S.; Giammanco, G.M.; Medici, M.C.; Ganesh, B.; L'Homme, Y.; Farkas, T.; Jakab, F.; et al. Analysis of the ORF2 of human astroviruses reveals lineage diversification, recombination and rearrangement and provides the basis for a novel sub-classification system. Arch. Virol. 2014, 159, 3185-3196. [CrossRef]

74. De Grazia, S.; Medici, M.C.; Pinto, P.; Moschidou, P.; Tummolo, F.; Calderaro, A.; Bonura, F.; Banyai, K.; Giammanco, G.M.; Martella, V. Genetic heterogeneity and recombination in human type 2 astroviruses. J. Clin. Microbiol. 2012, 50, 3760-3764. [CrossRef]

75. Babkin, I.V.; Tikunov, A.Y.; Zhirakovskaia, E.V.; Netesov, S.V.; Tikunova, N.V. High evolutionary rate of human astrovirus. Infect. Genet. Evol. 2012, 12, 435-442. [CrossRef]

76. Graham, R.L.; Baric, R.S. Recombination, Reservoirs, and the Modular Spike: Mechanisms of Coronavirus Cross-Species Transmission. J. Virol. 2010, 84, 3134-3146. [CrossRef] [PubMed]

77. Simmonds, P. Recombination and Selection in the Evolution of Picornaviruses and Other Mammalian Positive-Stranded RNA Viruses. J. Virol. 2006, 80, 11124-11140. [CrossRef]

78. Sánchez, C.M.; Izeta, A.; Sánchez-Morgado, J.M.; Alonso, S.; Sola, I.; Balasch, M.; Plana-Durán, J.; Enjuanes, L. Targeted recombination demonstrates that the spike gene of transmissible gastroenteritis coronavirus is a determinant of its enteric tropism and virulence. J. Virol. 1999, 73, 7607-7618. [CrossRef] [PubMed]

79. Cortez, V.; Meliopoulos, V.A.; Karlsson, E.A.; Hargest, V.; Johnson, C.; Schultz-Cherry, S. Astrovirus Biology and Pathogenesis. Annu. Rev. Virol. 2017, 4, 327-348. [CrossRef] [PubMed]

(C) 2020 by the authors. Licensee MDPI, Basel, Switzerland. This article is an open access article distributed under the terms and conditions of the Creative Commons Attribution (CC BY) license (http://creativecommons.org/licenses/by/4.0/). 